\title{
Phylogeny of the most species-rich freshwater bivalve family (Bivalvia: Unionida: Unionidae): Defining modern subfamilies and tribes
}

\author{
Manuel Lopes-Lima ${ }^{\mathrm{a}, *, 1}$, Elsa Froufe ${ }^{\mathrm{a}, 1}$, Van Tu Do ${ }^{\mathrm{b}}$, Mohamed Ghamizi ${ }^{\mathrm{c}}$, Karen E. Mock ${ }^{\mathrm{d}}$, Ümit Kebapçı ${ }^{\mathrm{e}}$, \\ Olga Klishko ${ }^{\mathrm{f}}$, Satit Kovitvadhi ${ }^{\mathrm{g}}$, Uthaiwan Kovitvadhi ${ }^{\mathrm{h}}$, Octávio S. Paulo ${ }^{\mathrm{i}}$, John M. Pfeiffer III ${ }^{\mathrm{j}}$, \\ Morgan Raley ${ }^{\mathrm{k}}$, Nicoletta Riccardi ${ }^{1}$, Hülya Şereflişan ${ }^{\mathrm{m}}$, Ronaldo Sousa ${ }^{\mathrm{a}, \mathrm{n}}$, Amílcar Teixeira ${ }^{ }$, \\ Simone Varandas ${ }^{\mathrm{p}}$, Xiaoping Wu ${ }^{\mathrm{q}}$, David T. Zanatta ${ }^{\mathrm{r}}$, Alexandra Zieritz ${ }^{\mathrm{s}}$, Arthur E. Bogan ${ }^{\mathrm{t}, 1}$
}

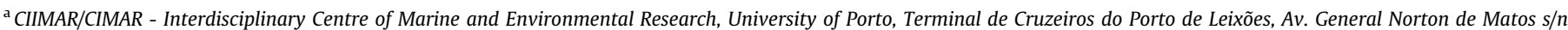 \\ 4450-208 Matosinhos, Portugal \\ ${ }^{\mathrm{b}}$ Department of Aquatic Ecology, Institute of Ecology and Biological Resources, Vietnam Academy of Science and Technology, 18 Hoang Quoc Viet, Cau Giay, Ha Noi, Viet Nam \\ ${ }^{\mathrm{c}}$ Muséum d'Histoire Naturelle de Marrakech, Université Cadi Ayyad, Faculté des Sciences, Semlalia, B.P. 2390 Marrakech, Morocco \\ ${ }^{\mathrm{d}}$ Ecology Center and Department of Wildland Resources, Utah State University, Logan, UT 84322, USA \\ e Department of Biology, Faculty of Arts and Sciences, Mehmet Akif Ersoy University, Burdur, Turkey \\ ${ }^{\mathrm{f}}$ Institute of Natural Resources, Ecology and Criology, Russian Academy of Sciences Siberian Branch, Chita 672014, Russia \\ ${ }^{\mathrm{g}}$ Department of Agriculture, Faculty of Science and Technology, Bansomdejchaopraya Rajabhat University, Bangkok 10600, Thailand \\ ${ }^{\mathrm{h}}$ Department of Zoology, Faculty of Science, Kasetsart University, Bangkok 10900, Thailand

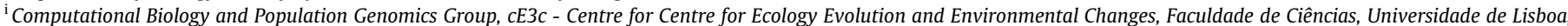 \\ Lisbon, Portugal \\ ${ }^{\mathrm{j}}$ Florida Museum of Natural History, University of Florida, Gainesville, FL 32611, USA \\ ${ }^{\mathrm{k}}$ HydroGENomics, Raleigh, NC 27606, USA \\ ${ }^{1}$ CNR - Institute for Ecosystems Studies, Verbania Pallanza (VB), Italy \\ ${ }^{\mathrm{m}}$ Faculty of Marine Sciences and Technology, İskenderun Technical University, 31200 Iskenderun, Hatay, Turkey \\ ${ }^{n}$ CBMA - Centre of Molecular and Environmental Biology, Department of Biology, University of Minho, Campus Gualtar, 4710-057 Braga, Portugal \\ ${ }^{\circ}$ CIMO/ESA/IPB - Mountain Research Centre, School of Agriculture, Polytechnic Institute of Bragança, Campus de Santa Apolónia, Apartado 1172, 5301-854 Bragança, Portugal

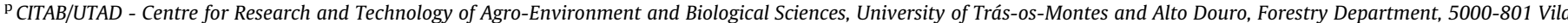 \\ Real, Portugal \\ ${ }^{\mathrm{q}}$ School of Life Sciences, Center for Watershed Ecology, Institute of Life Science, Nanchang University, Nanchang 330031, People's Republic of China \\ ${ }^{\mathrm{r}}$ Biology Department, Institute for Great Lakes Research, Central Michigan University, Biosciences Bldg. 2408, Mount Pleasant, MI 48859, USA \\ ${ }^{\mathrm{s}}$ School of Geography, University of Nottingham Malaysia Campus, Jalan Broga, 43500 Semenyih, Malaysia \\ ${ }^{\mathrm{t}}$ Research Laboratory, North Carolina State Museum of Natural Sciences, MSC 1626, Raleigh, NC 27699-1626, USA
}

\section{A R T I C L E I N F O}

\section{Article history:}

Received 25 February 2016

Revised 8 June 2016

Accepted 30 August 2016

Available online 9 September 2016

\section{Keywords:}

Mollusca

Systematics

Freshwater mussels

Taxonomy

Classification

\begin{abstract}
A B S T R A C T
Freshwater mussels of the order Unionida are key elements of freshwater habitats and are responsible for important ecological functions and services. Unfortunately, these bivalves are among the most threatened freshwater taxa in the world. However, conservation planning and management are hindered by taxonomic problems and a lack of detailed ecological data. This highlights the urgent need for advances in the areas of systematics and evolutionary relationships within the Unionida. This study presents the most comprehensive phylogeny to date of the larger Unionida family, i.e., the Unionidae. The phylogeny is based on a combined dataset of $1032 \mathrm{bp}(\mathrm{COI}+28 \mathrm{~S})$ of 70 species in 46 genera, with 7 of this genera being sequenced for the first time. The resulting phylogeny divided the Unionidae into 6 supported subfamilies and 18 tribes, three of which are here named for the first time (i.e., Chamberlainiini nomen novum, Cristariini nomen novum and Lanceolariini nomen novum). Molecular analyses were complemented by investigations of selected morphological, anatomical and behavioral characters used in traditional phylogenetic studies. No single morphological, anatomical or behavioral character was diagnostic at the subfamily level and few were useful at the tribe level. However, within subfamilies, many tribes can be recognized based on a subset of these characters. The geographical distribution of each of the subfamilies and tribes is also presented. The present study provides important advances in the systematics of these extraordinary taxa with implications for future ecological and conservation studies.
\end{abstract}

(c) 2016 Elsevier Inc. All rights reserved.

\footnotetext{
* Corresponding author.

E-mail address: lopeslima.ciimar@gmail.com (M. Lopes-Lima).

1 These authors contributed equally to the paper.
} 


\section{Introduction}

Understanding phylogenetic diversity is crucial for conservation prioritization of freshwater mussels (Bivalvia: Unionida), which are among the most threatened freshwater taxa in the world (IUCN, 2015; Lydeard et al., 2004). Due to their ecological and economic importance, interesting biological traits (e.g., a parasitic life with the reproductive dependence on a host fish and a particular form of mitochondrial inheritance called double uniparental inheritance; Barnhart et al., 2008; Breton et al., 2007; Hoeh et al., 1996, 2002a), scientific research on Unionida has grown in recent years (Haag, 2012; Lopes-Lima et al., 2014). However, taxon-based conservation efforts focused on the Unionidae are hindered by various phylogenetic and taxonomic uncertainties (e.g., Inoue et al., 2014; Pfeiffer et al., 2015), and many species, especially those outside of North America and Western Europe, have been assigned a Data Deficient status by the IUCN (Bogan and Roe, 2008; IUCN, 2015; Kohler et al., 2012).

The Unionidae is by far the most species rich family within the order Unionida, with 620 species in 142 genera (Bogan and Roe, 2008) widely distributed across the freshwater ecosystems of Europe, Asia, North America and Africa. The first classification of the global Unionidae fauna was attempted by Lea (1836, 1838, 1852, 1870), and later updated by Simpson $(1900,1914)$. These works, in which the marsupium (i.e., the gill structure where the eggs and larvae are brooded), anatomy, larvae type and umbo sculpture were used as key classification characters, divided the Unionidae into two subfamilies, Unioninae and Hyriinae (Table 1). Subsequently, A.E. Ortmann performed a series of studies on North American taxa including additional anatomical classification characters and divided the Unionidae into three subfamilies: Unioninae, Anodontinae and Lampsilinae (Table 1: Ortmann, 1910, 1911, 1912, 1919, 1921; Ortmann and Walker, 1922). In discussing his classification, Ortmann (1912) noted the inadequacy of shell characters to define families and subfamilies due to widespread convergences in shell morphology; a problem that was further discussed by Prashad (1931). Apart from regional works (e.g., Frierson, 1927; Haas, 1940; Iredale, 1934), little progress was made on Unionidae classification until the middle of the twentieth century, when Modell and Haas published their comprehensive classification systems (Table 1: Haas, 1969a,b; Modell, 1942, 1949, 1964). Both Haas and Modell classification systems used a set of morphological and anatomical characters, but relied heavily on shell morphology. Haas (1969a,b) classified the Unionidae into six subfamilies. One of these, i.e., the Hyriinae, combined species from South America and Australasia and would later be recognized as a distinct family. Modell $(1942,1949,1964)$ developed a more complex and inflated classification system, which organized the Unionidae genera in distinct families and multiple subfamilies. Both authors' use of highly variable conchological characters for classification above the genus level led to incoherent associations. Nevertheless, the work by Haas has been widely recognized as the more reliable in terms of representing generic and subgeneric distinctiveness and is considered as fundamental in establishing the main genera of the Unionida and in particular, the Unionidae (Roe and Hoeh, 2003). Concurrent with the work of Haas (1969a,b) and Modell (1942, 1949, 1964), an even more inflated classification scheme was proposed by Starobogatov (1970) and Zatravkin and Bogatov (1987), who relied on conchological differences and focused on the curvature of the frontal section of the valves. This system is merely typological and was disregarded by most of the western school of malacologists (see Graf, 2007) and emergent Russian studies (Bolotov et al., 2015; Klishko et al., 2014).
A comprehensive molecular phylogenetic study of the Unionidae has not been attempted to date, primarily due to the difficulties in developing a dataset of sufficient geographical and species coverage. The first classification system using a phylogenetic framework was published by Heard and Guckert (1970; Table 1) for the North American Unionida fauna. Disregarding shell characters, these authors used a broad anatomical and reproductive behavior character set within a phylogenetic context. Their analyses resulted in the division of the North American Unionidae into two families and several subfamilies. The subsequent development of powerful molecular and statistical tools, providing a basis for more objective approaches, has led to the publication of several studies on unionid phylogeny (e.g., Campbell and Lydeard, 2012a, b; Campbell et al., 2005; Davis, 1983, 1984; Davis and Fuller, 1981; Davis et al., 1977, 1981; Graf and Cummings, 2006; Hoeh et al., 1998, 2001, 2002b, 2009; Pfeiffer and Graf, 2013, 2015; Roe and Hoeh, 2003; Whelan et al., 2011; Zanatta and Murphy, 2006). In many of these studies, unionid genera or species that had been identified by morphological characters were not consistent with those revealed through molecular phylogenetic analyses (e.g., Campbell and Lydeard, 2012a,b; Nagel and Badino, 2001; Roe and Hoeh, 2003). Although the vast majority of these molecular studies have focused almost exclusively on North American and European taxa, geographic and taxonomic sampling has recently increased, particularly in Africa (Elderkin et al., 2016; Graf, 2013; Whelan et al., 2011) and Asia (Huang et al., 2002; Pfeiffer and Graf, 2013, 2015; Zhou et al., 2007; Zieritz et al., 2016).

Recent molecular phylogenetic studies have achieved considerable progress in describing the main divisions within the Unionidae (Campbell and Lydeard, 2012a, 2012b; Graf and Cummings, 2006; Pfeiffer and Graf, 2013, 2015; Whelan et al., 2011). The status of the North American Ambleminae with four recognized tribes has been recently confirmed (Table 1: Campbell and Lydeard, 2012a,b; Campbell et al., 2005). Studies including species from Africa and the Indotropics examined the subfamily Parreysiinae in detail and recognized several subfamilies (Table 1: Pfeiffer and Graf, 2015; Whelan et al., 2011). Despite the considerable recent progress (Huang et al., 2002; Pfeiffer and Graf, 2013, 2015; Zhou et al., 2007), the vast majority of unionid genera from the Eastern Palearctic and the Indotropics have never been analyzed in a modern phylogenetic framework.

Based on bibliographical research, the classification of the Unionidae was recently reviewed, establishing the currently accepted subdivisions of the Unionidae (Carter et al., 2011; Table 1). This classification divided the family into six subfamilies: the Ambleminae with a North and Central American distribution; the Parreysiinae with a disjunct distribution primarily in SubSaharan Africa and the Indian subcontinent; the Modellnaiinae with a single species from Thailand; the Rectidentinae with a South East Asian distribution; and two subfamilies, the Unioninae and Gonideinae, distributed through most of Asia, Europe, North Africa and west coast of North America.

In order to increase the success of ongoing and future management efforts and to inform conservation priorities more effectively, a better understanding of the evolutionary history of freshwater mussels is necessary. Our objective herein is to improve the understanding of unionid phylogeny through analysis of a combination of nuclear and mitochondrial molecular markers from a wide coverage of genera. In detail, this study aims to: (i) resolve the main phylogenetic relationships within the Unionidae; (ii) discuss the systematics, taxonomy and distribution of the recovered unionid subdivisions (subfamilies and tribes); and (iii) compare the obtained classification with those based on morphological characters. 
Table 1

Historical classification systems of the subfamilies and tribes now included in the Unionidae. (Blue) subfamilies; (red) tribes; $\left({ }^{n n}\right)$ nomen novum; (*) regional study; (?) rank uncertain.

\begin{tabular}{|c|c|c|c|c|c|c|c|c|c|c|}
\hline $\begin{array}{l}\text { Simpson } \\
(1900 / 1914)\end{array}$ & $\begin{array}{c}\text { Ortmann } \\
(1912)^{*}\end{array}$ & $\begin{array}{l}\text { Modell } \\
\text { (1942) }\end{array}$ & $\begin{array}{c}\text { Haas } \\
(1969 a, 1969 b)\end{array}$ & $\begin{array}{c}\text { Heard and } \\
\text { Guckert } \\
(1970)^{*}\end{array}$ & $\begin{array}{l}\text { Brandt } \\
(1974)^{*}\end{array}$ & $\begin{array}{c}\text { Graf and } \\
\text { Cummings } \\
(2007)\end{array}$ & $\begin{array}{l}\text { Bieler et al. } \\
\quad(2010)\end{array}$ & $\begin{array}{l}\text { Whelan et al. } \\
\text { (2011) }\end{array}$ & $\begin{array}{l}\text { Carter et al. } \\
\quad \text { (2011) }\end{array}$ & This Study \\
\hline $\begin{array}{l}\text { Unionidae } \\
\text { Unioninae } \\
\text { Hyriinae }\end{array}$ & $\begin{array}{l}\text { Unionidae } \\
\text { Unioninae } \\
\text { Anodontinae } \\
\text { Lampsilinae }\end{array}$ & $\begin{array}{l}\text { Unionidae } \\
\text { Unioninae } \\
\text { Anodontinae } \\
\text { Cafferiinae } \\
\text { Coelaturinae } \\
\text { Contradentinae } \\
\text { Hyriinae } \\
\text { Hyriopsinae } \\
\text { Lamellidentinae } \\
\text { Lamprotulinae } \\
\text { Nannonaiinae } \\
\text { Parreysiinae } \\
\text { Propehyridellinae } \\
\text { Quadrulinae } \\
\text { Rectidentinae } \\
\\
\text { Elliptionidae } \\
\text { Alasmidontinae } \\
\text { Ambleminae } \\
\text { Elliptioninae } \\
\text { Lampsilinae } \\
\text { Pleurobeminae } \\
\text { Margaritiferidae } \\
\text { Heudeaninae } \\
\text { Pseudodontinae } \\
\end{array}$ & $\begin{array}{l}\text { Unionidae } \\
\text { Alasmidontinae } \\
\text { Anodontinae } \\
\text { Hyriinae } \\
\text { Lampsilinae } \\
\text { Quadrulinae } \\
\text { Unioninae }\end{array}$ & $\begin{array}{l}\text { Unionidae } \\
\text { Unioninae } \\
\text { Anodontinae } \\
\text { Lampsilinae } \\
\text { Pleurobeminae } \\
\text { Popenaiadinae } \\
\text { Amblemidae } \\
\text { Ambleminae } \\
\text { Gonideinae } \\
\text { Megalonaiadinae }\end{array}$ & $\begin{array}{l}\text { Unionidae } \\
\text { Hyriopsinae } \\
\text { Pseudodontinae } \\
\text { Parreysiinae } \\
\text { Rectidentinae } \\
\text { Modellnaiinae }\end{array}$ & $\begin{array}{l}\text { Unionidae } \\
\text { Unioninae } \\
\text { Unionini } \\
\text { Anodontini } \\
\text { Ambleminae } \\
\text { Amblemini } \\
\text { Gonideini } \\
\text { Lampsilini } \\
\text { Pleurobemini } \\
\text { Quadrulini }\end{array}$ & $\begin{array}{l}\text { Unionidae } \\
\text { Unioninae } \\
\text { Unionini } \\
\text { Anodontini } \\
\text { Ambleminae } \\
\text { Amblemini } \\
\text { Lampsilini } \\
\text { ?Oxynaiini } \\
\text { Pleurobemini } \\
\text { Quadrulini } \\
\text { Coelaturinae } \\
\text { Gonideinae } \\
\text { Modellnaiinae } \\
\text { Parreysiinae } \\
\text { Rectidentinae }\end{array}$ & $\begin{array}{l}\text { Unionidae } \\
\text { Unioninae } \\
\text { Unionini } \\
\text { Anodontini } \\
\text { Ambleminae } \\
\text { Amblemini } \\
\text { Lampsilini } \\
\text { Pleurobemini } \\
\text { Quadrulini } \\
\text { Gonideinae } \\
\text { Modellnaiinae } \\
\text { Parreysiinae } \\
\text { Coelaturini } \\
\text { Oxynaiini } \\
\text { Parreysiini } \\
\text { Lamellidentini } \\
\text { Rectidentinae }\end{array}$ & $\begin{array}{l}\text { Unionidae } \\
\text { Unioninae } \\
\text { Unionini } \\
\text { Anodontini } \\
\text { Ambleminae } \\
\text { Amblemini } \\
\text { Lampsilini } \\
\text { Pleurobemini } \\
\text { Quadrulini } \\
\text { Gonideinae } \\
\text { Modellnaiinae } \\
\text { Parreysiinae } \\
\text { Rectidentinae }\end{array}$ & $\begin{array}{l}\text { Unionidae } \\
\text { Unioninae } \\
\text { Unionini } \\
\text { Ambleminae } \\
\text { Amblemini } \\
\text { Lampsilini } \\
\text { Pleurobemini } \\
\text { Quadrulini } \\
\text { Anodontinae } \\
\text { Anodontini } \\
\text { Cristariini }{ }^{n n} \\
\text { Lanceolariini }{ }^{n} \\
\text { Gonideinae } \\
\text { Gonideini } \\
\text { Chamberlainiini }{ }^{n n} \\
\text { Lamprotulini } \\
\text { Pseudodontini } \\
\text { Parreysiinae } \\
\text { Coelaturini } \\
\text { Oxynaiini } \\
\text { Parreysiini } \\
\text { Lamellidentini } \\
\text { Rectidentinae } \\
\text { Rectidentini } \\
\text { Contradentini } \\
\text { ?Modellnaiinae } \\
\end{array}$ \\
\hline
\end{tabular}

\section{Materials and methods}

\subsection{Taxon sampling}

All analyzed taxa are listed in Table 2. Taxa were chosen to cover all available genera of Unionidae subfamilies. Exceptions were made with regard to the North American subfamily Ambleminae (only up to three species per tribe were included) and the African/Asian subfamily Parreysiinae, since both of these subfamilies were studied in detail elsewhere (Campbell and Lydeard, 2012a,b; Campbell et al., 2005; Whelan et al., 2011). Taxa representative from all families of the subclass Palaeoheterodonta were also included (comprising all recognized Unionida families and from Neotrigonia, the marine sister group of the Unionida) (Giribet and Wheeler, 2002).

\subsection{DNA extraction, amplification and sequencing}

Whole genomic DNA was extracted from small foot tissue samples preserved in 96\% ethanol using a standard high-salt protocol (Sambrook et al., 1989) or the Jetquick tissue DNA Spin Kit (Genomed) following the manufacturer's protocol. PCR conditions for both markers, the female lineages of mitochondrial cytochrome $c$ oxidase subunit 1, COI (LCO22me2 + HCO700dy2; Walker et al., 2006, 2007; and LCO1490 + HCO2198; Folmer et al., 1994) and 28S ribosomal RNA (28S-RD1.3f and 28S-rD4b; Whiting, 2002) were described in Froufe et al. (2014). Annealing temperatures of $48{ }^{\circ} \mathrm{C}$ were used for COI (LCO1490 + HCO2198) and 28S; and $50{ }^{\circ} \mathrm{C}$ for COI (LCO22me2 + HCO700dy2). Amplified DNA templates were purified and sequenced by the commercial company Macrogen using the same primers.

\subsection{Phylogenetic analyses}

Two concatenated $(\mathrm{COI}+28 \mathrm{~S})$ data sets were assembled, the Palaeoheterodonta dataset with representatives from each of the families of the Palaeoheterodonta (Appendix A) and, in order to decrease the number of poorly aligned positions of the $28 \mathrm{~S}$, the Unionidae dataset with only representatives of the Unionidae (Appendix B). Both datasets were aligned using the stand-alone version of GUIDANCE (version 1.5, Penn et al., 2010) with the MAFFT multiple sequence alignment algorithm (version 7, Katoh and Standley, 2013). The following GUIDANCE parameters were used: GUIDANCE score algorithm; 100 bootstrap replicates; a sequence cutoff score of 0.0 (no sequence removal); a column cutoff score of 0.0 (no columns removal); global pair alignment. Incongruence Length Difference (ILD) tests were performed to investigate incongruence between them (Farris et al., 1994).

The best-fit models of nucleotide substitution under the corrected Akaike Information Criterion were selected using JModelTest 2.1.8 (Darriba et al., 2012) for each partition, of the subsequent analyses.

For the Palaeoheterodonta dataset (Appendix A), a single scheme with 4 partitions was applied, model GTR + I + G was optimal for the first and third COI codon positions and for the whole 28S, while model F81 was optimal for the second COI codon positions. For the Unionidae dataset (Appendix B) more comprehensive analyses were executed including two distinct partitioning schemes; the first with two partitions corresponding to each gene fragment (COI and 28S) and the second with four partitions corresponding to the three codon positions of COI and one for 28S. For the scheme with 2 partitions, model GTR + I $+G$ was optimal for both. For the scheme with 4 partitions, model GTR + I + G was optimal for the first COI codon positions and for the 28S, while model F81 was optimal for the second COI codon positions. Finally, model GTR + G was optimal for the third positions of COI.

Two different analyses were then performed on all partitioned schemes of the concatenated datasets using Bayesian Inference (BI) (BI2: 2 partitions, BI4: four partitions) and Maximum Likelihood analyses (ML) (ML2: 2 partitions, ML4: 4 partitions). BI analyses were performed in MrBayes v3.2.5 (Ronquist et al., 2012) 
Table 2

Specimens analyzed. $\left({ }^{U}\right)$ Unknown country; $(*)$ not generated from a single individual. Taxonomy follows Table 3.

\begin{tabular}{|c|c|c|c|c|c|}
\hline Taxon & $\mathrm{COI}$ & $28 \mathrm{~S}$ & Country & Reference & Voucher \\
\hline \multicolumn{6}{|l|}{ UNIONIDAE } \\
\hline \multicolumn{6}{|l|}{ ANODONTINAE } \\
\hline \multicolumn{6}{|l|}{ ANODONTINI } \\
\hline Alasmidonta marginata Say, 1818 & AF156502 & AF400688 & USA & Graf and Foighil (2000); Graf and Cummings (2006) & \\
\hline Anodonta anatina (Linnaeus, 1758) & KX822632 & KX822588 & Russia & This study & \\
\hline Anodonta cygnea (Linnaeus, 1758) & KX822633 & KX822589 & Italy & This study & \\
\hline Anodonta nuttalliana Lea, 1838 & KX822634 & KX822590 & USA & This study & \\
\hline Lasmigona compressa (Lea, 1829) & AF156503 & DQ191414 & USA & Graf and Foighil (2000); Graf and Cummings (2006) & \\
\hline Pseudanodonta complanata (Rossmässler, 1835) & KX822661 & KX822617 & Ukraine & This study & \\
\hline Pyganodon grandis (Say, 1829)* & AF231734 & AF305384 & USA & Bogan and Hoeh (2000); Graf and Foighil (2000) & \\
\hline Simpsonaias ambigua (Say, 1825) & KX822666 & KX822622 & USA & This study & NCSM30607 \\
\hline Strophitus undulatus (Say, 1817)* & AF156505 & DQ191415 & USA & Graf and Foighil (2000); Graf and Cummings (2006) & \\
\hline \multicolumn{6}{|l|}{ CRISTARIINI } \\
\hline Anemina arcaeformis (Heude, 1877) & KF667530 & KX822587 & China & An et al. (2016); this study & \\
\hline Cristaria plicata (Leach, 1814) & KX822637 & KX822594 & Russia & This study & \\
\hline Pletholophus tenuis (Griffith \& Pidgeon, 1833) & KX822658 & KX822614 & Vietnam & This study & NCSM84924 \\
\hline Sinanodonta lucida (Heude, 1877) & KX822667 & KX822624 & China & This study & \\
\hline Sinanodonta woodiana (Lea, 1834) & KX822668 & KX822625 & Vietnam & This study & NCSM84916 \\
\hline \multicolumn{6}{|l|}{ LANCEOLARIINI } \\
\hline Arconaia lanceolata (Lea, 1856) & NC_023955 & KX822591 & China & Wang et al. (2016); this study & \\
\hline Lanceolaria gladiola (Heude, 1877) & KX822648 & KX822605 & China & This study & \\
\hline Lanceolaria grayana (Lea, 1834$)$ & KX822649 & KX822606 & China & This study & \\
\hline Lanceolaria grayii (Griffith \& Pidgeon, 1833) & KX822650 & KX822607 & Vietnam & This study & NCSM84945 \\
\hline \multicolumn{6}{|l|}{ UNIONINAE } \\
\hline \multicolumn{6}{|l|}{ UNIONINI } \\
\hline Unio crassus Philipsson, 1788* & KC703878 & KC703644 & France & Prié and Puillandre (2014) & \\
\hline Unio gibbus Spengler, 1793 & KX822671 & KX822629 & Morocco & This study & \\
\hline Unio pictorum (Linnaeus, 1758) & KC429109 & KC429447 & U(Europe) & Sharma et al. (2013) & \\
\hline Unio tumidus Philipsson, 1788 & KX822672 & KX822630 & Ukraine & This study & \\
\hline \multicolumn{6}{|l|}{ Incertae sedis (UNIONINAE) } \\
\hline Aculamprotula tortuosa (Lea, 1865) & KX822631 & KX822586 & China & This study & \\
\hline Cuneopsis heudei (Heude, 1874) & KX822638 & KX822595 & China & This study & \\
\hline Cuneopsis pisciculus (Heude, 1874) & KX822639 & KX822596 & China & This study & \\
\hline Cuneopsis rufescens (Heude, 1874) & KX822640 & KX822597 & China & This study & \\
\hline Nodularia douglasiae (Griffith \& Pidgeon, 1833) & KX822653 & KX822610 & China & This study & \\
\hline Nodularia nuxpersicae Dunker, 1848 & KX822654 & KX822611 & Vietnam & This study & NCSM84990 \\
\hline Schistodesmus lampreyanus (Baird \& Adams, 1867) & KX822665 & KX822621 & China & This study & \\
\hline \multicolumn{6}{|l|}{ RECTIDENTINAE } \\
\hline CONTRADENTINI & & & & & \\
\hline Contradens contradens (Lea, 1838) & DQ191411 & AF400692 & $\mathrm{U}_{\text {(Asia })}$ & Graf and Cummings (2006) & \\
\hline Contradens semmelinki fultoni Haas, 1930 & KX822636 & KX822593 & Vietnam & This study & NCSM84935 \\
\hline Physunio modelli Brandt, 1974 & KX822655 & KX822612 & Thailand & This study & \\
\hline Trapezoideus exolescens (Gould, 1843) & КР795036 & КР795018 & Laos & Pfeiffer and Graf (2015) & \\
\hline RECTIDENTINI & & & & & \\
\hline Ensidens ingallsianus (Lea, 1852) & KX822641 & KX822598 & Laos & This study & NCSM84889 \\
\hline Ensidens sagittarius (Lea, 1856) & КР795033 & КР795015 & Cambodia & Pfeiffer and Graf (2015) & \\
\hline Ensidens sp. & KX822642 & KX822599 & Laos & This study & NCSM84902 \\
\hline Hyriopsis bialata Simpson, 1900 & KX822643 & KX822600 & Thailand & This study & \\
\hline Hyriopsis desowitzi Brandt, 1974 & KX822644 & KX822601 & Thailand & This study & \\
\hline Hyriopsis myersiana (Lea, 1856) & KX822645 & KX822602 & Thailand & This study & \\
\hline Rectidens sumatrensis (Dunker, 1852) & KX822664 & KX822620 & Malaysia & This study & \\
\hline GONIDEINAE & & & & & \\
\hline CHAMBERLAINIINI & & & & & \\
\hline Chamberlainia hainesiana (Lea, 1856) & KX822635 & KX822592 & Thailand & This study & \\
\hline Sinohyriopsis cumingii (Lea, 1852)* & HM347668 & KX822623 & China & Unpublished; this study & \\
\hline LAMPROTULINI & & & & & \\
\hline Lamprotula caveata (Heude, 1877) & KX822646 & KX822603 & China & This study & \\
\hline Lamprotula leaii (Griffith \& Pidgeon, 1833) & KX822647 & KX822604 & China & This study & \\
\hline Potomida littoralis (Cuvier, 1798) & JN243905 & JN243883 & France & Whelan et al. (2011) & \\
\hline Pronodularia japanensis (Lea, 1859) & KX822659 & KX822615 & Japan & This study & NCSM27183 \\
\hline GONIDEINI & & & & & \\
\hline Gonidea angulata (Lea, 1838)* & DQ272371 & AF400691 & USA & Gustafson and Iwamoto (2005); Graf (2002) & \\
\hline Leguminaia wheatleyi (Lea, 1862) & KX822651 & KX822608 & Turkey & This study & \\
\hline Microcondylaea bonellii (A. Ferussac 1827) & KX822652 & KX822609 & Italy & This study & \\
\hline Solenaia carinata (Heude, 1877) & KX822669 & KX822626 & China & This study & \\
\hline Solenaia oleivora (Heude, 1877) & KX822670 & KX822627 & China & This study & \\
\hline PSEUDODONTINI & & & & & \\
\hline Pilsbryoconcha compressa (Martens, 1860) & KX822656 & KX822613 & Thailand & This study & \\
\hline Pilsbryoconcha exilis (Lea, 1838)* & KX822657 & AF400693 & Vietnam & Graf (2002); this study & \\
\hline Pseudodon cambodjensis (Petit de la Saussaye, 1865) & KX822660 & KX822616 & Thailand & This study & \\
\hline Pseudodon cumingii (Lea, 1850) & KX822662 & KX822618 & Laos & This study & NCSM84884 \\
\hline Pseudodon mouhotii (Lea, 1863) & KX822663 & KX822619 & Laos & This study & NCSM84903 \\
\hline Incertae sedis (GONIDEINAE) & & & & & \\
\hline Solenaia triangularis (Heude, 1885) & KJ434518 & KX822628 & China & This study & \\
\hline
\end{tabular}


Table 2 (continued)

\begin{tabular}{|c|c|c|c|c|c|}
\hline Taxon & $\mathrm{COI}$ & $28 \mathrm{~S}$ & Country & Reference & Voucher \\
\hline \multicolumn{6}{|l|}{ AMBLEMINAE } \\
\hline \multicolumn{6}{|l|}{ AMBLEMINI } \\
\hline Amblema plicata (Say, 1817) & APU56841 & AF305385 & USA & Hoeh et al. (1998); Graf (2002) & \\
\hline \multicolumn{6}{|l|}{ LAMPSILINI } \\
\hline Actinonaias ligamentina (Lamarck, 1819) & AF156517 & DQ191420 & USA & Graf and Foighil (2000); Graf and Cummings (2006) & \\
\hline Lampsilis cardium Rafinesque, $1820 *$ & AF120653 & AF305386 & USA & Giribet and Wheeler (2002); Graf (2002) & \\
\hline Villosa iris (Lea, 1829) & AF156524 & DQ191422 & USA & Graf and Foighil (2000); Graf and Cummings (2006) & \\
\hline \multicolumn{6}{|l|}{ PLEUROBEMINI } \\
\hline Elliptio complanata (Lightfoot, 1786)* & EU448173 & JF899181 & USA & Unpublished; Distel et al. (2011) & \\
\hline Elliptio dilatata (Rafinesque, 1820 )* & AF156507 & AF400690 & USA & Graf and Foighil (2000); Graf (2002) & \\
\hline Pleurobema sintoxia (Rafinesque, 1820) & AF156509 & DQ191418 & USA & Graf and Foighil (2000); Graf and Cummings (2006) & \\
\hline \multicolumn{6}{|l|}{ QUADRULINI } \\
\hline Quadrula quadrula (Rafinesque, 1820) & AF156511 & DQ191417 & USA & Graf and Foighil (2000); Graf and Cummings (2006) & \\
\hline Quadrula verrucosa (Rafinesque, 1820) & DQ191413 & DQ191416 & USA & Graf and Cummings (2006) & \\
\hline \multicolumn{6}{|l|}{ PARREYSIINAE } \\
\hline \multicolumn{6}{|l|}{ COELATURINI } \\
\hline Coelatura aegyptiaca (Cailliaud, 1827) & JN243892 & JN243870 & Egypt & Whelan et al. (2011) & \\
\hline \multicolumn{6}{|l|}{ LAMELLIDENTINI } \\
\hline Lamellidens corrianus (Lea, 1834) & JN243903 & JN243881 & Burma & Whelan et al. (2011) & \\
\hline \multicolumn{6}{|l|}{ OXYNAIINI } \\
\hline Oxynaia pugio (Benson, 1862) & JN243899 & JN243879 & Burma & Whelan et al. (2011) & \\
\hline \multicolumn{6}{|l|}{ PARREYSIINI } \\
\hline Parreysia mandelayensis (Theobald, 1873) & JN243900 & JN243876 & Burma & Whelan et al. (2011) & \\
\hline \multicolumn{6}{|l|}{ TRIGONIIDAE } \\
\hline Neotrigonia margaritacea (Lamarck, 1804)* & NMU56850 & AF400695 & Australia & Hoeh et al. (1998); Graf (2002) & \\
\hline \multicolumn{6}{|l|}{ HYRIIDAE } \\
\hline Hyridella depressa (Lamarck, 1819) & AF156496 & AF305375 & Australia & Graf and Foighil (2000); Graf (2002) & \\
\hline Velesunio ambiguus (Philippi, 1847) & KC429106 & KC429444 & Australia & Sharma et al. (2013) & \\
\hline \multicolumn{6}{|l|}{ MARGARITIFERIDAE } \\
\hline Cumberlandia monodonta (Say, 1829) & AF156497 & AF305382 & USA & Graf and Foighil (2000); Graf (2002) & \\
\hline Margaritifera margaritifera (Linnaeus, 1758) & KC429108 & KC429446 & $\mathrm{U}_{\text {(Europe) }}$ & Sharma et al. (2013) & \\
\hline \multicolumn{6}{|l|}{ ETHERIIDAE } \\
\hline Etheria elliptica Lamarck, 1807 & KP184897 & KP184873 & Zambia & Graf et al. (2015) & \\
\hline \multicolumn{6}{|l|}{ IRIDINIDAE } \\
\hline Aspatharia pfeifferiana (Bernardi, 1860) & JN243885 & JN243863 & Zambia & Whelan et al. (2011) & \\
\hline Chambardia wahlbergi (Krauss, 1848) & JN243886 & JN243864 & Zambia & Whelan et al. (2011) & \\
\hline Mutela rostrata (Rang, 1835) & JN243884 & JN243862 & Egypt & Whelan et al. (2011) & \\
\hline \multicolumn{6}{|l|}{ MULLERIIDAE } \\
\hline Anodontites elongata (Swainson, 1823) & JN243888 & JN243866 & Peru & Whelan et al. (2011) & \\
\hline Mycetopoda siliquosa (Spix \& Wagner, 1827) & JN243887 & JN243865 & Peru & Whelan et al. (2011) & \\
\hline
\end{tabular}

using the previously selected models. Analyses were initiated with program-generated trees and four Markov chains with default incremental heating. Two independent runs of $24 \times 10^{6}$ generations were sampled at intervals of 1000 generations producing a total of 24,000 trees. Burn-in was determined upon convergence of log likelihood and parameter values using Tracer 1.6 (Rambaut et al., 2014).

For the ML phylogenetic analyses, sequences were analyzed in RaxML 8.0.0 (Stamatakis, 2014) where GTR + G+I model was assumed for each partition with 1000 bootstrap replicates.

\subsection{Review of morphological, anatomical, and behavioral traits}

A table of morphological characters commonly used for Unionidae systematics was constructed using a compilation of the available literature and direct observations of the analyzed taxa. To characterize and compare glochidial size, the glochidial size index (Gln) was calculated following Davis and Fuller (1981) where Gln = glochidial shell length $(\mu \mathrm{m}) \times$ shell height $(\mu \mathrm{m}) \times 10^{-6}$. Gln was divided into three size classes: small $(\leqslant 0.020)$, medium $(>0.020$ and $\leqslant 0.070)$ and large $(>0.070)$. These classes were determined using all glochidia measurements collected for this study (Table C1) and those included in Barnhart et al. (2008) and Hoggarth (1999); the smaller size range of Quadrulini was used to define the class 'small'; the larger size range of Anodontini was used to define the class 'large'; and the 'medium' class size was defined with intermediate Gln values between the two other classes.

\subsection{Distribution}

Distribution maps were constructed using data available from the IUCN database (IUCN, 2015), the Mussel Project website (Graf and Cummings, 2016), the North Carolina Museum of Natural Sciences database (NCMNS, 2016), and additional reference works (Bogatov, 2012; Bogatov and Starobogatov, 1992; Brandt, 1974; Clarke, 1981; Cyr et al., 2007; Đ ng et al., 1980; Doucet-Beaupré et al., 2012; Haas, 1969a,b; He and Zhuang, 2013; Howells et al., 1996; Klishko, 2001, 2003; Kondo, 2008; Moskvicheva, 1973a,b; Nedeau et al., 2009; Prozorova and Bogatov, 2006; Subba Rao, 1989; Vinarski et al., 2007; Zatravkin and Bogatov, 1987; Zhadin, 1938). Because distribution data were gathered and compiled from very distinct sources, ranging from georeferenced data points, hydrographic basins and geographical regions or countries, the distributions on the maps are represented with various patterns (e.g., political borders or hydrographic basins).

\section{Results and discussion}

Previous phylogenetic studies of the Unionidae failed to include most of the genera, mainly those from the Eastern Palearctic and Indotropical ecoregions. We were able to clarify the phylogeny within Unionidae by the inclusion of samples from a wide coverage of genera and geographic distribution.

On both of the following ( $\mathrm{COI}+28 \mathrm{~S}$ ) datasets, no indels were observed in the COI alignments and no stop codons were found 
after translating the sequences to amino acids. The ILD tests found no significant phylogenetic conflict between the COI and $28 \mathrm{~S}$ for the Palaeoheterodonta $(p=0.95)$ and the Unionidae $(p=0.94)$ datasets.

The Palaeoheterodonta dataset $(\mathrm{COI}+28 \mathrm{~S})$ included 81 species in 55 genera, with a total of $1091 \mathrm{bp}$ (COI: $597 \mathrm{bp}, 28 \mathrm{~S}$ : $494 \mathrm{bp}$ ). Since the same topology in the supported nodes was obtained in the resulting phylogenetic trees, the BI4 (Bayesian Inference with 4 partitions, see methods) topology is here presented in Fig. 1. These analyses revealed the monophyly of the Unionidae in all analyses with six supported subfamilies supported by the BI analysis (Anodontinae, Unioninae, Rectidentinae, Gonideinae, Ambleminae, and Parreysiinae) showing the Parreysiinae as a sister clade to all of the other Unionidae.

The dataset including only Unionidae taxa spanned 70 species in 46 genera, with a total of 1032 bp (COI: 597 bp, 28S: 435 bp) aligned nucleotides. All resulting phylogenetic trees yielded the same topology up to the tribal level, being the BI4 (Bayesian Inference with 4 partitions, see methods) topology presented. Both BI topologies were generally associated wtih higher bootstrap support levels than ML topologies. Furthermore, the BI4 topology resulted in slightly higher bootstrap values than the BI2 topology, presumably due to distinct COI mutation rates.

The Unionidae is divided in two major clades, which are well supported in all analyses and partition schemes, i.e., Anodontinae + Unioninae and Rectidentinae + Gonideinae + Ambleminae (Fig. 2). At the subfamily level most clades are supported by the Bayesian analyses, with the Rectidentinae also being supported by both ML analyses (Fig. 2). At the tribal level the same trend is observed, with all four analyses supporting Contradentini, Rectidentini, Chamberlainiini, Lamprotulini, with the remaining tribes being supported mostly by BI analyses only.

The subfamily Anodontinae is divided into three tribes (i.e., Anodontini, Cristariini nomen novum and Lanceolariini nomen novum), and the subfamily Unioninae is not well resolved, with Unionini being the only supported tribe. Available tribe names for the currently unsupported group (sister to the Unionini) include Acuticostinae Starobogatov, 1967 and Nodulariinae Starobogatov and Zatravkin, 1987. The subfamily Rectidentinae is sister to Gonideinae + Ambleminae and encompasses two tribes (i.e., Contradentini and Rectidentini). Both Gonideinae and Ambleminae are divided into four tribes each (see Fig. 2). In summary, our molecular phylogenetic analyses revealed division of the Unionidae into 6 subfamilies and 18 tribes, three of which are named here for the first time. Revisions pertaining to the subfamilial and tribal classification within the Unionidae are discussed here along with a number of number of lower-level phylogenetic and taxonomic considerations.

To complement the present molecular analyses, seven morphological, anatomical and behavioral characters commonly used in traditional classifications of the Unionidae are summarized for each taxon in Table C1.

Glochidial shape is diagnostic in dividing the Anodontinae + Unioninae (triangular) and Rectidentinae + Gonideinae + Ambleminae (bilaterally asymmetrical or semi-elliptical) clades (Table C1). No single morpho-behavioral character analyzed herein is diagnostic of subfamilies within these clades. However, within subfamilies, certain tribes are characterized by unique diagnostic characters. Within Anodontinae, four characteristics (shell shape, hinge structure, glochidial size and brooding period) separate the Lanceolariini from the Anodontini + Cristariini. Additionally, all taxa within the Lanceolariini analyzed are characterized by nodulous umbo sculpture, although this morphological character is highly variable within all other subfamilies and tribes (Table C1). Within Rectidentinae, glochidial shape is diagnostic in separating the Contradentini (bilaterally asymmetrical) and Rectidentini (semi-elliptical). Among the four tribes in Gonideinae, the Chamberlainiini taxa are unique in exhibiting ectobranchous marsupia (Table C1).

\subsection{Classification system}

Based on the present results, a new classification of the Unionidae is presented, including the description of three new tribes: Cristariini Lopes-Lima, Bogan and Froufe, 2016; Lanceolariini Froufe, Lopes-Lima and Bogan, 2016; and Chamberlainiini Bogan, Froufe and Lopes-Lima, 2016 (Table 3).

\subsection{Anodontinae Rafinesque, 1820 phylogeny and tribal classification}

The subfamily status of the Anodontinae was first defined by Rafinesque in 1820 and properly Latinized by Fleming in 1828. The subfamily status was retained in many of the classical classifications well in to the 20th century (e.g., Davis and Fuller, 1981; Haas, 1969a,b; Heard and Guckert, 1970; Modell, 1964; Ortmann, 1910). Subsequent studies demoted Anodontinae to a tribe within Unioninae due to the shared hooked type and subtriangular external shape of the glochidia (Bieler et al., 2010; Carter et al., 2011; Graf, 2002; Graf and Cummings, 2007). However, the rank change of Anodontinae into Anodontini has been recently disputed based on morphology discrepancies in glochidia morphology (Huang et al., 2013). Anodontinae and Unioninae are here recovered as sister clades and due to the ancient divergence of the two clades are herein considered as subfamilies, in accordance with traditional classifications. Within Anodontinae, we recognize three distinct tribes. In traditional classifications, this subfamily was characterized by a set of distinctive morphological (e.g., large and ovate thin shells, and large triangular and hooked glochidia), anatomical (e.g., demibranchs with perforated septa, secondary water tubes in the outer demibranchs, and marsupium in the external demibranch pair that distend laterally upon gravidity) and ecological (e.g., most species seem to be generalists concerning habitat and host fish) characters. Although all of the above characters are found in most of the species within Anodontini and Cristariini, the Lanceolariini present characters more similar to those of the Unioninae (i.e., shell size and form, glochidial size, and tachytictia).

Members of the Anodontinae have a wide distribution in the Northern Hemisphere, not occuring in most of the Indotropical, and glaciated or desert regions (Fig. 3).

\subsubsection{Tribe Anodontini Rafinesque, 1820}

Type Genus: Anodonta Lamarck, 1799

Type Species: Mytilus cygneus Linnaeus, 1758

Comments: The Anodontini include one supported clade that contains all analyzed Anodontinae genera from Eastern North America, while the relationships among the Anodonta and Pseudanodonta species are not well resolved. The Anodontini encompass the genera Alasmidonta, Anodonta, Lasmigona, Pseudanodonta, Pyganodon, Simpsonaias, Strophitus (Fig. 2), Anodontoides, Arcidens, and Utterbackia (Table 3; Breton et al., 2011; Inoue et al., 2014; Lydeard et al., 1996; Zanatta et al., 2007). Due to the lack of molecular data, two genera usually assigned to this tribe, i.e., Simpsonella from the Philippines and Pegias from North America (Graf and Cummings, 2016; Haas, 1969a,b), are not included in the present molecular analyses. Placement of both these genera within the tribe thus remains to be tested by molecular methods. This will be of particular interest regarding Simpsonella, which has a disjunct distribution and has been placed within the Contradentini in other studies (Modell, 1942, 1964). We recovered two main clades within the Anodontini: one with Palearctic genera including the 


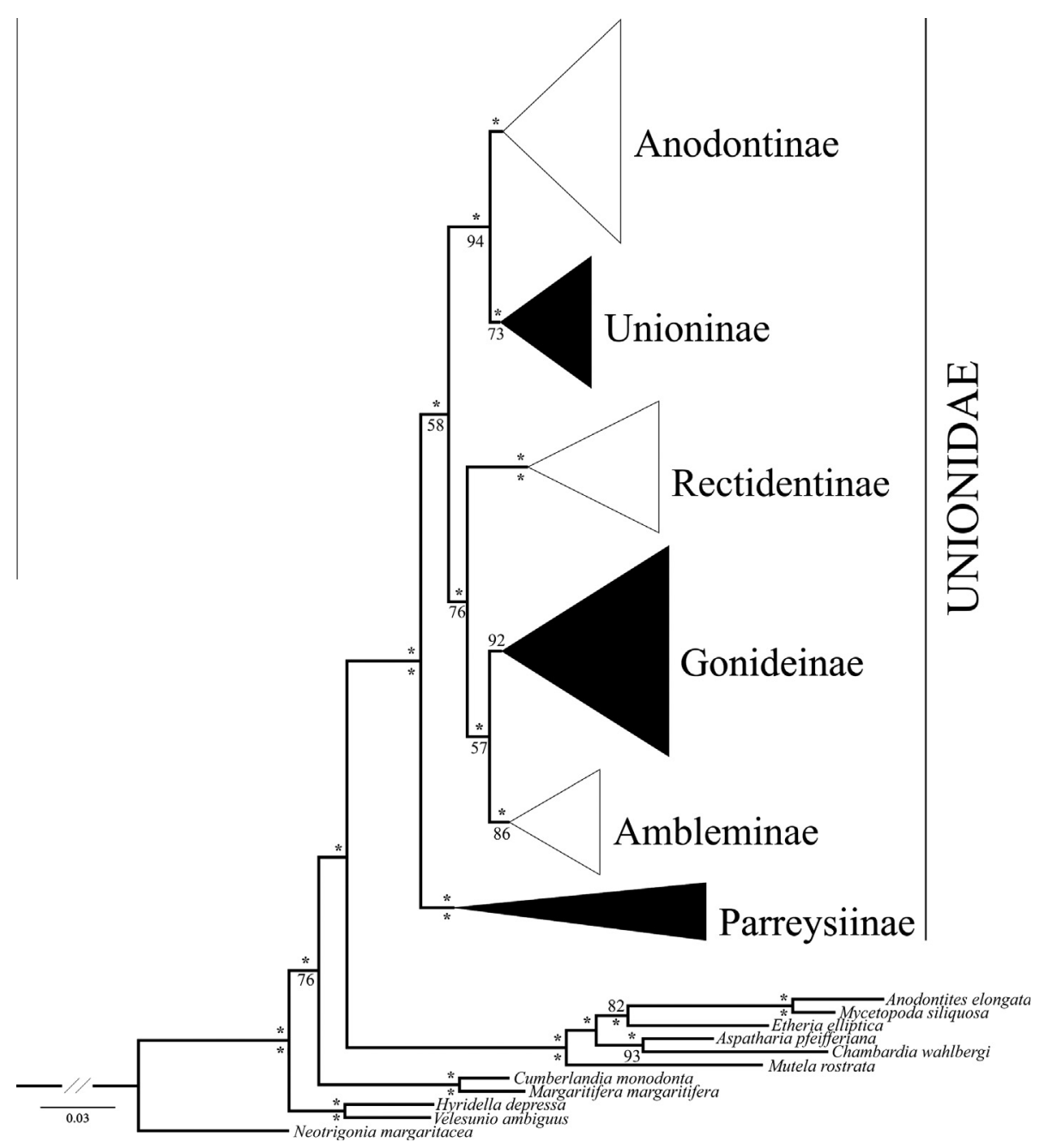

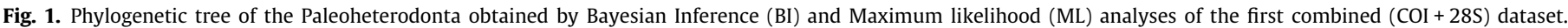

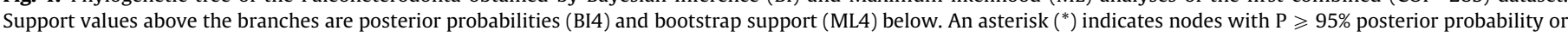

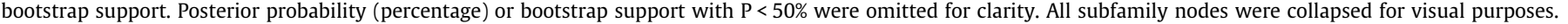

type genus Anodonta that is also present in the West coast of North America and the other including all East coast North American genera (Figs. 2 and 3). The relationships among and within genera in each of these clades are not well resolved and should be further investigated.

Diagnosis: Shell is commonly thin and ovate to elongate but with some exceptions, mainly in Alasmidonta and Lasmigona spp. (Table C1). Hinge is generally toothless or with vestigial teeth in some genera e.g., Alasmidonta, Lasmigona and Strophitus. Umbo sculpture is varied and composed of double-looped and/or pseudo-concentric and/or single-looped ridges, which are sometimes wrinkled or nodulous. Glochidia are large, triangular, and ventrally hooked with spines (Table C1).

Distribution: The Anodontini have a disjunct distribution from the Western Palearctic to the Transbaikalia and on both North American coasts (Fig. 3). Almost all Eastern Asian Anodontinae species previously ascribed to Anodonta (e.g., A. woodiana and A. arcaeformis) have later been transferred to other genera that are now placed outside Anodontini (Haas, 1969a,b; Kondo, 2008). The only Anodonta species still recognized from East Asia, Anodonta beringiana, should be reassigned to the genus Sinanodonta (Chong et al., 2008). The presence of the tribe Anodontini in Central America and Middle East is pending further evaluation of the phylogenetic status of Anodonta lurulenta Morelet, 1849, Anodonta pseudodopsis Locard, 1883 and Anodonta vescoiana Bourguignat, 1856.

\subsubsection{Tribe Cristariini Lopes-Lima, Bogan and Froufe, nomen novum}

Type Genus: Cristaria Schumacher, 1817

Type Species: Cristaria tuberculata Schumacher, 1817; junior synonym of Dipsas plicata Leach, 1815.

Comments: The Cristariini include one supported clade composed by the genera Anemina, Cristaria, Pletholophus and Sinanodonta (Fig. 2; Table 3). The type genus Cristaria is not monophyletic in the current analyses and since Cristaria plicata is the type species, Cristaria tenuis is here reassigned to Pletholophus Simpson, 1900 following $Đ$ ng et al. (1980), He and Zhuang (2013) and Simpson (1900, 1914). Many species have been assigned to Sinanodonta, primarily by the Russian school of nomenclature (Graf, 2007; Haas, 1969a), but validity of these placements should be tested using molecular tools. Sinanodonta lucida was first described as Anodonta lucida and then assigned to Sinanodonta ( $¥$ ng et al., 1980) but both generic attributions are still being used (e.g., Huang et al., 2013; Pfeiffer and Graf, 2013). Additionally, recent studies based on morphological data consider $S$. lucida as a synonym of S. woodiana (Graf and Cummings, 2016; He and Zhuang, 2013). Due to the high genetic distance between these two taxa (12.3\%; COI uncorrected $p$-distance), Sinanodonta woodiana and Sinanodonta lucida are here recognized as two distinct species. Finally, as mentioned above, Anodonta beringiana, although 


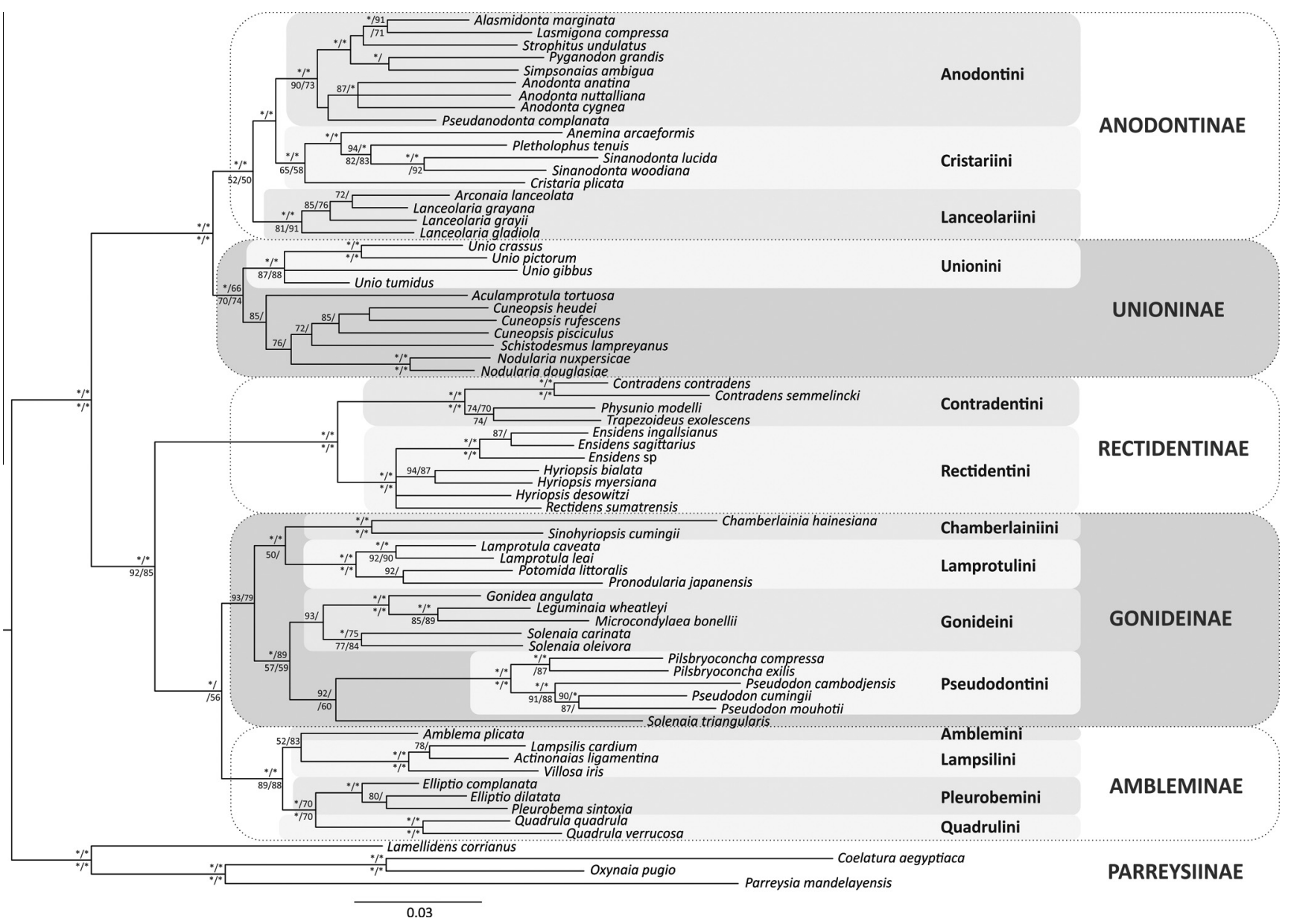

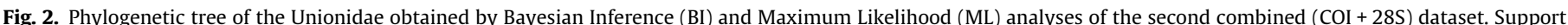

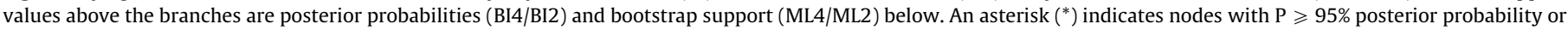
bootstrap support. Posterior probability or bootstrap support with $\mathrm{P}<50 \%$ were omitted for clarity.

not included in the present analysis, should be placed within the Cristariini though its generic assignment remains to be investigated.

Diagnosis: Shell is usually thin, of elliptical to oval shape, with or without a posterior dorsal wing. Umbo rather low, sculpture usually consisting of pseudo-concentric folds that are nearly parallel to growth lines. Periostracum is usually rayed. Hinge is lacking in Anemina and Sinanodonta, but reduced lamellar lateral and pseudocardinal teeth may be present in Cristaria and Pletholophus.

Distribution: The native range of Cristariini spans from Indochina to China, Korea, Japan, the Sakhalin Island, Amur Basin, Kamchatka and Chukotka Peninsulas (in Russia) to the Aleutians and the Pacific Coastal Region of North America, where it may be found as far south as Oregon (Fig. 3).

\subsubsection{Tribe Lanceolariini Froufe, Lopes-Lima and Bogan, nomen novum}

Type Genus: Lanceolaria Conrad, 1853

Type Species: Unio grayanus Lea, 1834

Comments: The tribe Lanceolariini is sister to all other Anodontinae. Most of its shell morphological characteristics appear more similar to the subfamily Unioninae (e.g., well-developed hinge teeth, medium sized glochidia and tachytictia; Table C1). It is therefore not surprising that all previous classifications placed the genera of this tribe within the Unioninae rather than in
Anodontinae (e.g., Haas, 1969a, 1969b; Starobogatov, 1970). Lanceolariini encompasses two genera, i.e., Arconaia Conrad, 1865 and Lanceolaria Conrad, 1853, though this should be further investigated considering that our results indicate paraphyly of Lanceolar$i a$, giving support for the monotypic status of Lanceolariini with Lanceolaria as the single genus.

Diagnosis: Shell is rather thick, of elongate or lanceolate shape and in some taxa, with antero-posterior torsion. Umbo is low and positioned near the anterior end. Umbo sculpture is strictly nodulous and usually restricted to the umbo area but in some cases more widespread. Pseudocardinal teeth are well developed and long; lateral teeth are straight and thick.

Distribution: Lanceolariini are restricted to Far East Asia, from the Amur River basin (Russia) to Japan, Korea, the Pacific basins of China and Vietnam (Fig. 3).

\subsection{Unioninae Rafinesque, 1820 phylogeny and tribal classification}

The Unioninae were one of the first defined subfamilies, and the subfamily level has been retained in all subsequent classifications of the Unionidae (Table 1). Until the middle of the 20th century, this subfamily encompassed almost all of the unionid genera of Europe, Africa and Asia with the exception of those assigned to Anodontinae (Haas, 1969a,b). It later became obvious that the Unioninae represented a simple collection of very distinct groups that were not related or similar in most of their characters. In this context, the Unionidae were subdivided by Modell $(1942,1964)$ 
Table 3

Classification of the Unionidae based on the present analyses. $(*)$ Not included in the present study.

ANODONTINAE Rafinesque, 1820

Anodontini Rafinesque, 1820

+ Alasmidontini Rafinesque, 1820

+ Strophitini Starobogatov, 1970

+ Pseudanodontini Starobogatov, 1970

+ Brachanodonini Bogatov, Sayenko and Starobogatov, 2002

*Arcidens Simpson, 1900 [+ Arkansia Ortmann \& Walker 1912]

Alasmidonta Say, 1818

Anodonta Lamarck, 1799

*Anodontoides Simpson in F.C Baker, 1898

Lasmigona Rafinesque, 1831

Pseudanodonta Bourguignat, 1876

Pyganodon Crosse \& Fischer, 1894

Simpsonaias, Frierson, 1914

Strophitus Rafinesque, 1820

*Utterbackia F.C. Baker, 1927

Cristariini Lopes-Lima, Bogan and Froufe, Nom. Nov.

Anemina Haas, 1969

Cristaria Schumacher, 1817

Pletholophus Simpson, 1900

Sinanodonta Modell, 1945

Lanceolariini Froufe, Lopes-Lima and Bogan, Nom. Nov.

Arconaia Conrad, 1865

Lanceolaria Conrad, 1853

ANODONTINAE (incertae sedis)

*Pegias Simpson, 1900

*Simpsonella Cockerell, 1903

UNIONINAE Rafinesque, 1820

+ Cafferiinae Modell, 1942

Unionini Rafinesque, 1820

+ Cafferiini Modell, 1942

Unio Philipsson in Retzius, 1788

UNIONINAE (incertae sedis)

Aculamprotula Wu, Liang, Wang \& Ouyang, 1998

$*$ Acuticosta Simpson, 1900

Cuneopsis Simpson, 1900

*Inversiunio Habe, 1991

*Lepidodesma Simpson, 1896

Nodularia Conrad, 1853

*Rhombuniopsis Haas, 1920

Schistodesmus Simpson, 1900

RECTIDENTINAE Modell, 1942

+ Hyriopsinae Modell, 1942

Contradentini Modell, 1942

+ Physunioini Starobogatov, 1970

Contradens Haas, 1913

Physunio Simpson, 1900

Trapezoideus Simpson, 1900

Rectidentini Modell, 1942

+ Limnoscaphini Lindholm, 1932

Ensidens Frierson, 1911

Hyriopsis Conrad, 1853

Rectidens Simpson, 1900

GONIDEINAE Ortmann, 1916

+ Leguminainae Starobogatov, 1970

Chamberlainiini Bogan, Froufe and Lopes-Lima, Nom. Nov.

Chamberlainia Simpson, 1900

Sinohyriopsis Starobogatov, 1970

Lamprotulini Modell, 1942

+ Psilunionini Starobogatov, 1970

Lamprotula Simpson, 1900

Potomida Swainson, 1840

Pronodularia Starobogatov, 1970

Gonideini Ortmann, 1916

+ Leguminaiini Starobogatov, 1970

Gonidea Conrad, 1857

Leguminaia Conrad, 1865

Microcondylaea Vest, 1866

Solenaia Conrad, 1869

Pseudodontini Frierson, 1927

Pseudodon Gould, 1844

Pilsbryoconcha Simpson, 1900

GONIDEINAE (incertae sedis)

*Discomya Simpson, 1900

*Inversidens Haas, 1911
Solenaia triangularis

AMBLEMINAE Rafinesque, 1820

Amblemini Rafinesque, 1820

Amblema Rafinesque, 1820

*Reginaia Campbell and Lydeard, 2012

Lampsilini Ihering 1901

+ Propterini Hannibal, 1912

+ Cyprogeniini Starobogatov, 1970

+ Dromini Starobogatov, 1970

+ Friersoniini Starobogatov, 1970

+ Glebulini, Starobogatov, 1970

+ Medionidinae Starobogatov, 1970

+ Pilaeini Starobogatov, 1970

+ Pileini Bieler et al. 2010

+ Popenaiadini Heard and Guckert, 1970

+ Ptychobranchini Starobogatov, 1970

Actinonaias Crosse \& Fischer, 1894

*Arotonaias von Martens, 1900

*Cyprogenia Agassiz, 1852

*Cyrtonaias Crosse \& Fischer, 1894

*Dromus Simpson, 1900

*Ellipsaria Rafinesque, 1820

*Epioblasma Rafinesque, 1831

*Friersonia Ortmann, 1912

*Glebula Conrad, 1853

*Hamiota Roe \& Hartfield, 2005

Lampsilis Rafinesque, 1820

*Lemiox Rafinesque, 1831

*Leptodea Rafinesque, 1820

*Ligumia Swainson, 1840

*Medionidus Simpson, 1900

*Obliquaria Rafinesque, 1820

*Obovaria Rafinesque, 1819

*Plectomerus Conrad, 1853

*Popenaias Frierson, 1927

*Potamilus Rafinesque, 1818

*Ptychobranchus Simpson, 1900

*Toxolasma Rafinesque, 1831

*Truncilla Rafinesque, 1819

*Venustaconcha Frierson, 1927

Villosa Frierson, 1927

Pleurobemini Hannibal, 1912

+ Elliptionini, Modell, 1942

Elliptio Rafinesque, 1820

*Elliptoideus Frierson, 1927

*Fusconaia Simpson, 1900

*Hemistena Rafinesque, 1820

*Plethobasus Simpson, 1900

Pleurobema Rafinesque, 1819

*Pleuronaia Frierson, 1927

Quadrulini Ihering, 1901

+ Megalonaiadini Heard and Guckert, 1970

*Cyclonaias Pilsbry in Ortmann \& Walker, 1922

*Megalonaias Utterback, 1915

Quadrula Rafinesque, 1820

*Tritogonia Agassiz, 1852

*Uniomerus Conrad, 1853

AMBLEMINAE (incertae sedis)

*Barynaias Crosse \& Fischer, 1894

*Delpinonaias Crosse \& Fischer, 1894

*Disconaias Crosse \& Fischer, 1894

*Martinsnaias Frierson, 1927

*Micronaias Simpson, 1900

*Nephritica Frierson, 1927

*Nephronaias Crosse \& Fischer, 1894

*Pachynaias Crosse \& Fischer, 1894

*Psoronaias Crosse \& Fischer, 1894

*Psorula Haas, 1930

*Reticulataus Frierson, 1927

*Sphenonaias Crosse \& Fischer, 1894

PARREYSIINAE Henderson 1935

Parreysiini Henderson, 1935

+ Diplasminae Modell, 1942

+ Hemisolasminae Starobogatov, 1970

Parreysia Conrad, 1853

Coelaturini Modell, 1942

+ Brazzaeini Leloup, 1950

+ Dentaspainiini Modell, 1964 
+ Mweruellini Pain and F.R. Woodward, 1968

+ Prisodontopsini Pain and F.R. Woodward, 1968

+ Pseudaviculini Modell, 1942 [not available name, Bouchet and Rocroi, 2010]

+ Pseudospathini Leloup, 1950 [not available name, Bouchet and Rocroi, 2010]

+ Pseuodspathinae Starobogatov, 1970

*Brazzaea Bourguignat, 1885

Coelatura Conrad, 1853

*Grandidieria Bourguignat, 1885

*Mweruella Haas, 1936

*Nitia Pallary, 1924

*Nyassunio Haas, 1936

*Prisodontopsis Tomlin1928

*Pseudospatha Simpson, 1900

Lamellidentini Modell, 1942

Lamellidens. Simpson, 1900

Oxynaiini Starobogatov, 1970

Oxynaia Haas, 1911

*Radiatula Simpson, 1900

*Scabies Haas, 1911

PARREYSIINAE (incertae sedis)

*Germainaia Graf \& Cummings, 2009

MODELLNAIINAE Brandt, 1974

*Modellnaia Brandt 1974

UNIONIDAE (incertae sedis)

*Arcidopsis Simpson, 1900 [Arcidopsinae Starobogatov 1970]

*Caudiculatus Simpson, 1900

*Ctenodesma Simpson, 1900

*Diaurora Cockerell, 1903

*Elongaria Haas, 1913

*Gibbosula Simpson, 1900

*Haasodonta McMichael, 1956

*Harmandia Rochebrune, 1882

*Pressidens Haas, 1910

*Prohyriopsis Haas, 1914

*Protunio Haas, 1913

*Pseudodontopsis Kobelt, 1913

*Pseudobaphia Simpson, 1900

*Pseudomulleria Anthony, 1907 [Pseudomulleriinae Starobogatov, 1970]

*Ptychorhynchus Simpson, 1900

*Schepmania Haas, 1912

*Unionetta Haas, 1955

into several subfamilies using umbo sculpture as the main diagnostic character (Table 1). However, this character alone was clearly unsuitable for this purpose and thus, these subfamilies were lumped back together until emergence of modern phylogenetic approaches (Davis and Fuller, 1981; Heard and Guckert, 1970). Since then, several Asian and African genera have been reassigned to other subfamilies based on molecular phylogenetic analyses and morphology (Huang et al., 2002; Kondo, 2008; Liu et al., 1979; Ouyang et al., 2011; Pfeiffer and Graf, 2013, 2015; Zhou et al., 2007). In addition, many genera within this subfamily have never been characterized using a molecular approach.

In the present study, one well supported clade, i.e., the tribe Unionini, was obtained within the Unioninae. Phylogenetic relationships among the remaining genera are not well resolved. The phylogeny recovered Aculamprotula as sister to a clade including Cuneopsis + Schistodesmus + Nodularia, but with poor support. As a result, Aculamprotula, Cuneopsis, Schistodesmus and Nodularia were classified as incertae sedis within Unioninae. If future phylogenetic analyses that include additional taxa give support to the clade Cuneopsis + Schistodesmus + Nodularia, the available name would be Nodulariini Starobogatov and Zatravkin, 1987 since the subfamily name Cuneopsinae Mongin, 1963 is not an available name (Bieler et al., 2010). Furthermore, if in future studies the genus Acuticosta falls within this clade the earliest tribe name would change to Acuticostini Starobogatov, 1967.

As in the Anodontinae, the Unioninae present a strict ectobranchy condition, but see Araujo et al. (2009) and Lopes-Lima et al. (2016a) for unusual exceptions in some populations.
Marsupial demibranchs lack specialized characters present in Anodontinae. Hinge teeth are well-defined. Glochidia are hooked, triangular and of medium size. Brooding type is tachytictic or short term (Table C1). The Unioninae are one of the most widely distributed tribes, covering almost all of Europe and Northwest Africa, as well as Vietnam, China, Far East Russia, Korea, Japan and the Sakhalin Island. In addition, two Unio species have disjunct distributions, i.e., Unio abyssinicus in the Horn of Africa and Unio caffer in South Africa (Fig. 4).

\subsubsection{Tribe Unionini Rafinesque, 1820}

Type Genus: Unio Philipsson in Retzius, 1788

Type Species: Mya pictorum Linnaeus, 1758

Comments: The Unionini contain only one genus, i.e., Unio. This genus is divided into four main lineages, i.e., the crassus-, pictorum-, gibbus- and tumidus-lineages (Froufe et al., 2016a; LopesLima et al., 2016b), all of which are represented in the present phylogeny. Whilst the crassus- and pictorum-lineages cluster together, relationships among this group and the other two Unio lineages are not well resolved (Fig. 2).

Diagnosis: The main shared characters of the Unionini are: ectobranchous; marsupial demibranch without any specialized character; presence of a well-defined hinge structure with two pseudocardinal and two lateral teeth on the left valve and one or two on the right; umbo sculpture W-shaped and/or doublelooped bars, which in some cases become nodulous or wrinkled; tachytictia or short term brooding; and the hooked triangular glochidia of intermediate sizes (Table C1).

Distribution: The tribe has essentially a western Palearctic distribution, extending from Western Europe to European Russia and the Caspian basin. In addition, three disjunct distributions are known, i.e., one in the Transbaikal region in Russia and two others in Sub-Saharan Africa (Fig. 4).

\subsection{Rectidentinae Modell, 1942 phylogeny and tribal classification}

The Rectidentinae originally included Rectidens as the type genus, as well as Physunio and Ensidens also including some eastern North American and South Eastern Asian genera in this subfamily (e.g., Lastena, Pyganodon and Pilsbryoconcha) (Modell, 1942, 1964), but these were subsequently reassigned to distinct subfamilies (Haas, 1969a). The present phylogeny reveals two well supported clades within Rectidentinae, i.e., the tribes Contradentini Modell, 1942 and Rectidentini Modell, 1942. The Contradentini were first described as a subfamily in the same study that defined Rectidentinae (Modell, 1942). Although the Rectidentinae, Contradentinae and Nannonaiinae were all described by Modell (1942), priority of Rectidentinae was determined by the First Revisor action (Bieler et al., 2010; Brandt, 1974).

Since the two tribes within the Rectidentinae show a wide variability in morphological and anatomical characters, none of these characteristics are distinctive on the subfamily level (Table C1). The Rectidentinae are restricted to South East Asia, i.e., from Eastern India to Myanmar, Thailand, Laos, Cambodia and Vietnam, and to Peninsular Malaysia, and the Islands of Sumatra, Java, Borneo and Sulawesi (Fig. 5).

\subsubsection{Tribe Contradentini Modell, 1942}

Type Genus: Contradens Haas, 1911

Type Species: Contradens contradens (Lea, 1838)

Comments: The Contradentini initially included the type genus Contradens, as well as Caudiculatus, Pressidens and Simpsonella, all 


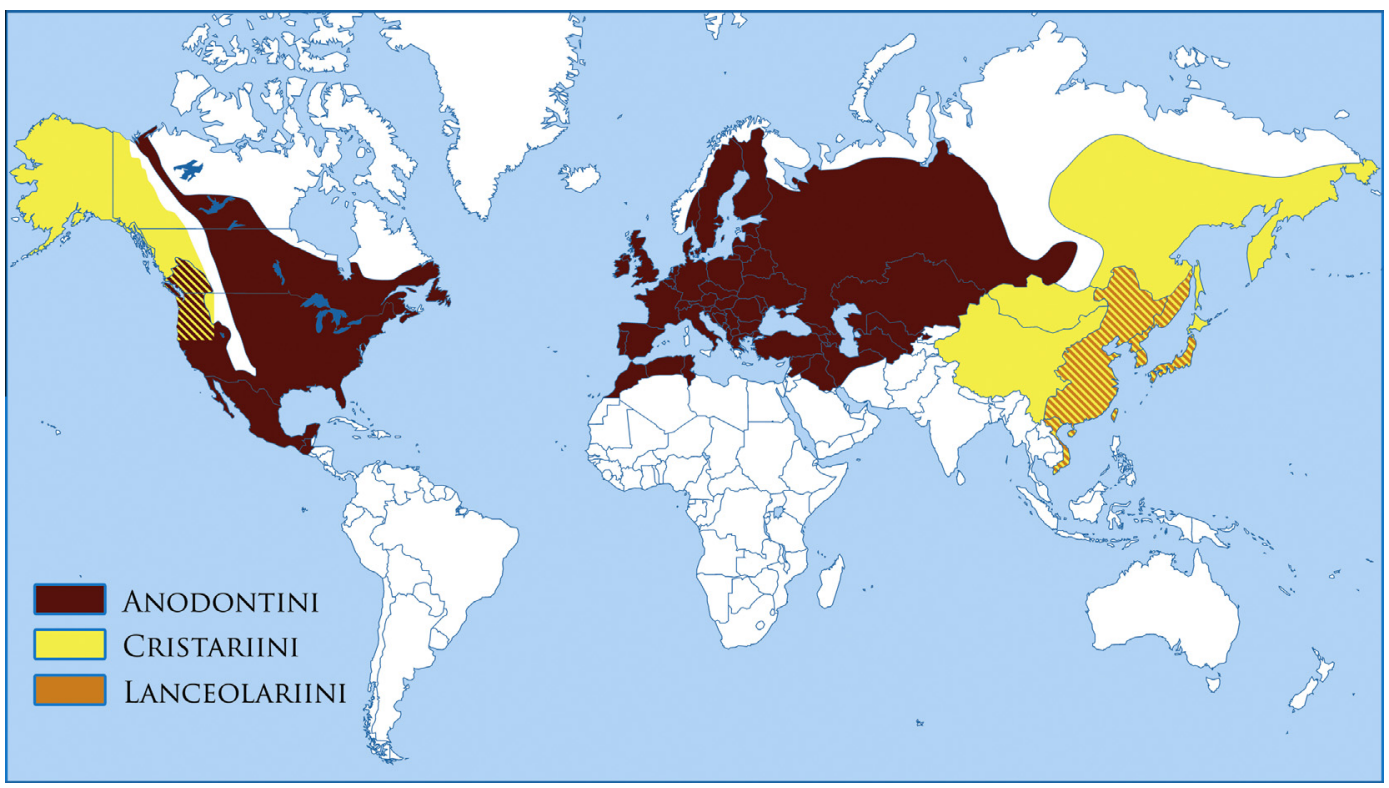

Fig. 3. Distribution map of the subfamily Anodontinae.

from Indochina and the Island of Borneo and the Philippines (Modell, 1942, 1964). Subsequently, all of these genera were reassigned to the Unioninae, with the exception of Simpsonella, which was placed within the Anodontinae (Haas, 1969a,b). More recently, Caudiculatus and Pressidens were once again placed within the Rectidentinae (Graf and Cummings, 2016). The present analyses recovered three genera in Contradentini, i.e., Contradens, Physunio and Trapezoideus. The phylogenetic relationships of the other genera, i.e., Caudiculatus, Pressidens and Simpsonella should be further investigated, since no sequence data are available at present. The date of publication of two genera, i.e., Uniandra Haas and Contradens, has been a source of confusion and has been clarified by Bogan (2015).

Diagnosis: Shell shape is variable, from rounded to elongate. Umbo sculpture ranges from v-shaped (e.g., in Contradens contradens) to $\mathrm{w}$-shaped/double-looped/nodulous (e.g., in Physunio superbus) and pseudo-concentric ridges (e.g., in Trapezoideus exolescens). Hinge plate is well defined, with one lateral and one or two thin pseudocardinal teeth in the left valve, and one lateral and one pseudocardinal teeth in the right valve. Glochidia are bilaterally asymmetrical and are quite distinct from any other group of the Unionidae, rendering this trait diagnostic of the tribe (Pfeiffer and Graf, 2015). Brooding type is ectobranchous, but brooding period and length are unknown.

Distribution: The Contradentini have the same distribution in South East Asia as described above for the Rectidentinae (Fig. 5).

\subsubsection{Tribe Rectidentini Modell, 1942}

Type Genus: Rectidens Simpson, 1900

Type Species: Unio lingulatus Drouet and Chaper, 1892

Comments: The Rectidentini include the type genus Rectidens as well as Hyriopsis and Ensidens. Of the four Hyriopsis species included in this study, only Hyriopsis cumingii does not cluster with the type of the genus Hyriopsis bialata. Thus, Hyriopsis cumingii is here reassigned to Sinohyriopsis Starobogatov, 1970, with the type species Unio cumingii Lea, 1852 (see $Đ$ ng et al., 1980). The remaining Hyriopsis species relationships, i.e., Hyriopsis bialata, Hyriopsis desowitzi and Hyriopsis myersiana are still unresolved.
Diagnosis: Shells are usually elongated and, in Hyriopsis, often with evident dorsal wings. Umbo sculpture is predominantly pseudo-concentric to double-looped or nodulous. Hinge structure is generally well defined with a variety of teeth number and shapes. Glochidia are of the unhooked elliptical type and of intermediate sizes. Brooding type is ectobranchous or tetragenous in Hyriopsis and tetragenous in Ensidens and Rectidens (Table C1). The semi-elliptical unhooked shape of Rectidentini glochidia distinguishes this tribe from the Contradentini. However, semielliptical unhooked glochidia are also present in other subfamilies (i.e., Gonideinae and Ambleminae, Modellnaiinae, and Parreysiinae).

Distribution: Although the distribution of the Rectidentini significantly overlaps with that of the Contradentini, its range excludes Bangladesh and the Islands of Sulawesi and Sumatra (Fig. 5).

\subsection{Gonideinae Ortmann, 1916 phylogeny and tribal classification}

The Gonideinae was first described including only a single monotypic genus, i.e., Gonidea angulata (Lea, 1838), which had previously been assigned to Anodontinae (Ortmann, 1916). That species reassignment was based on the distinctive anatomical characters of $G$. angulata, which are unique among the North American unionid fauna (Ortmann, 1916). Since then, the phylogenetic position of $G$. angulata has changed many times. It has been recognized as a valid subfamily (Heard and Guckert, 1970; Ortmann, 1916), placed within other subfamilies such as the Pseudodontinae (Modell, 1942) and the Unioninae (Haas, 1969a, 1969b), and in a separate tribe, i.e., Gonideini, within the Ambleminae (Graf, 2002; Graf and Cummings, 2007), but always as a monotypic group. Recent molecular phylogenetic analyses have recovered Gonidea in a clade with several Old World genera (e.g., Potomida, Pseudodon and Pronodularia) and recognized that clade as the Gonideinae (Pfeiffer and Graf, 2013, 2015).

In the present work, the Gonideinae are recovered as a monophyletic subfamily that includes the type genus Gonidea from western North America, three Western Palearctic genera (i.e., Leguminaia, Microcondylaea and Potomida) and seven genera from East and Southeast Asia. The Gonideinae are here divided into two well supported clades. One includes two sister tribes, i.e., Chamberlainiini nomen novum and Lamprotulini (Fig. 2). The second clade is 


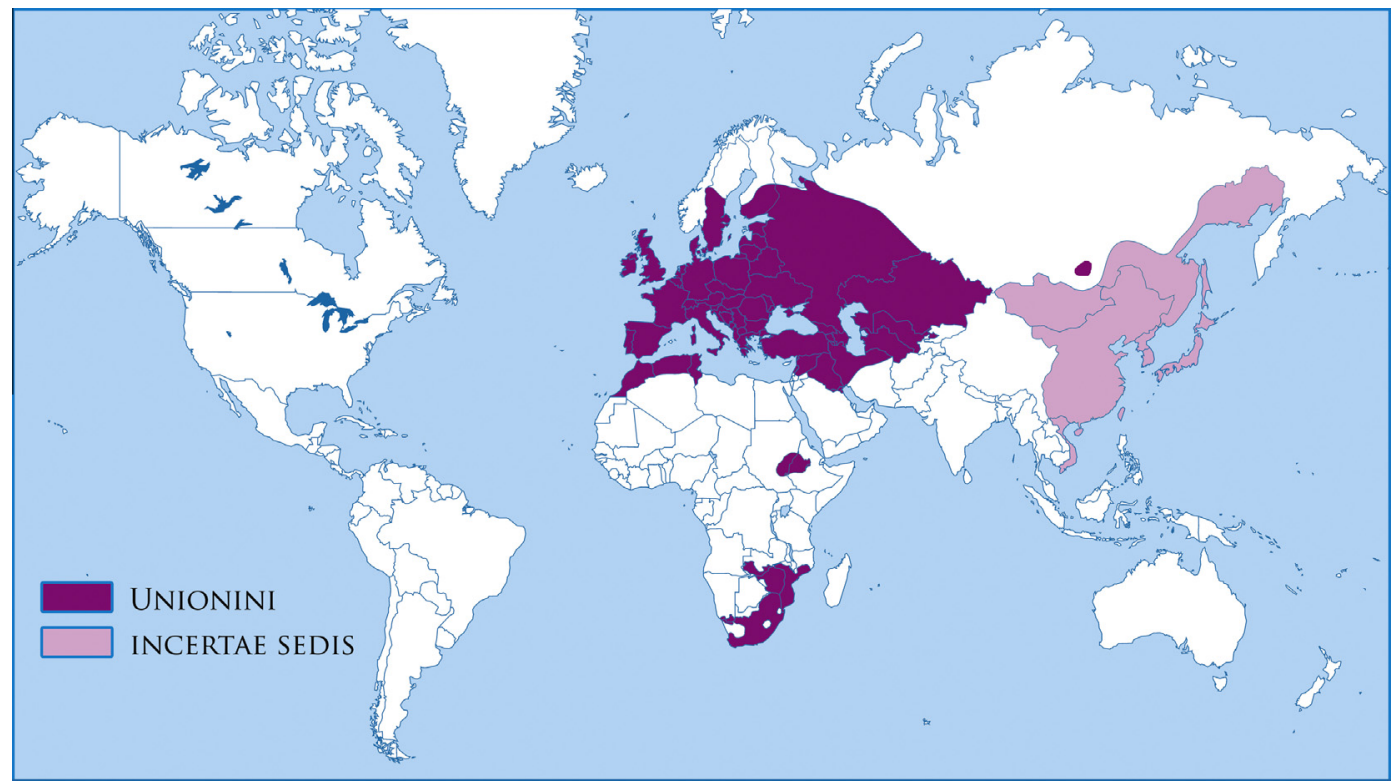

Fig. 4. Distribution map of the subfamily Unioninae.

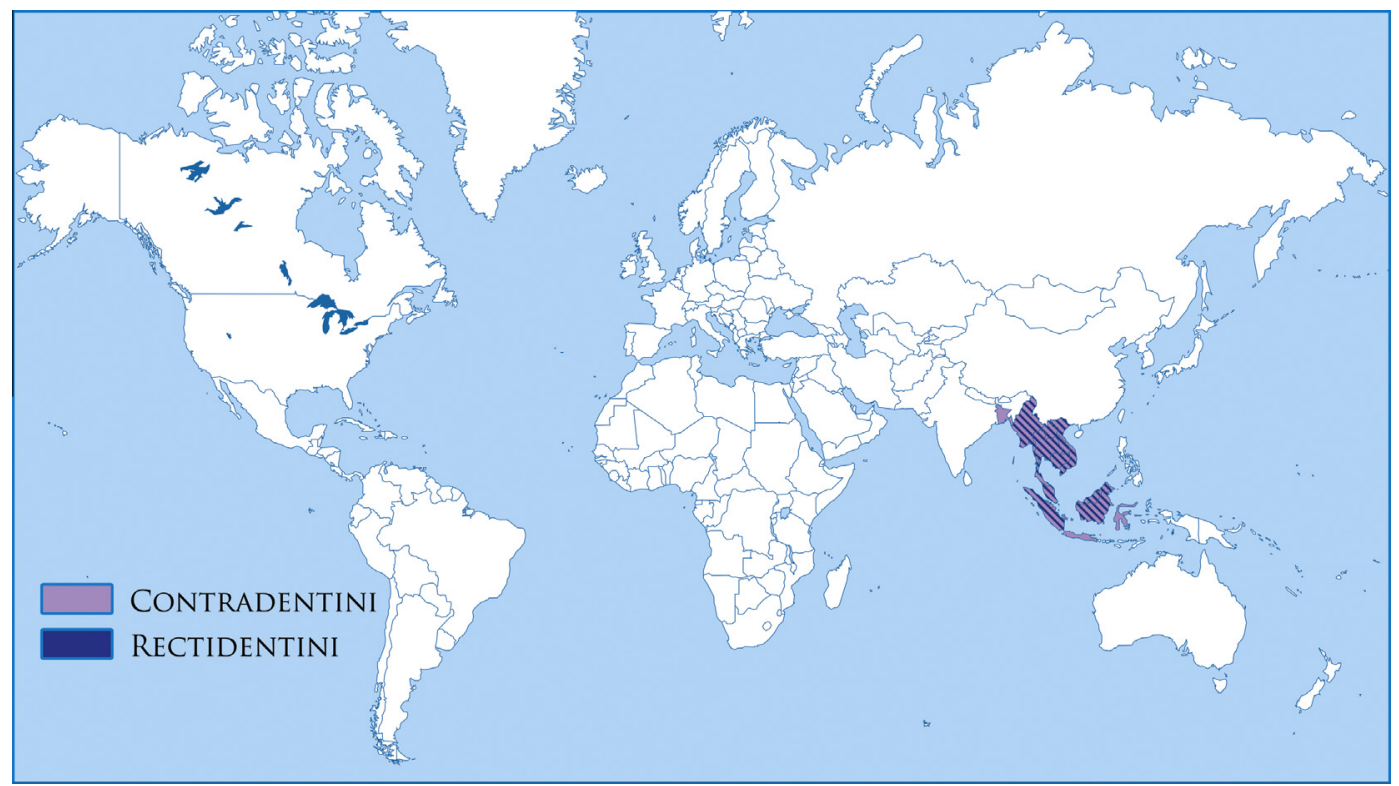

Fig. 5. Distribution map of the subfamily Rectidentinae.

composed of two tribes, i.e., the Gonideini and the Pseudodontini, and one isolated species, i.e., Solenaia triangularis (Fig. 2). No single morphological character is useful to diagnose the subfamily. All of the studied genera have medium sized semi-elliptical unhooked glochidia and are tachytictic, though the marsupium location varies among tribes (i.e., ectobranchous or tetragenous; Table C1). The Gonideinae have a scattered distribution in the Northern Hemisphere, being present in restricted regions of the Palearctic, Indotropics and Western Nearctic (Fig. 6).

\subsubsection{Tribe Chamberlainiini Bogan, Froufe and Lopes-Lima, nomen novum}

Type Genus: Chamberlainia Simpson, 1900

Type Species: Unio hainesianus Lea, 1856
Comments: Chamberlainiini nomen novum is here described for the first time and encompasses only two genera, i.e., the monotypic Chamberlainia and Sinohyriopsis. The latter includes Sinohyriopsis cumingii, previously assigned to Hyriopsis (see above), and Sinohyriopsis schlegelii, previously shown to be related to $S$. cumingii (Froufe et al., 2016b).

Diagnosis: Shell oval, elliptical to rhomboid, often with small anterior wing and posterior dorsal wing. Posterior ridge is rounded. Umbos are low. Umbo sculpture consisting of well-developed pseudo-concentric or nodulous ridges. Hinge with single pseudocardinal and lateral tooth in the right valve, and typically two pseudocardinal and lateral teeth in left valve. Glochidia, as in all Gonideinae, are unhooked and semi-elliptical in shape. Brooding type is ectobranchous and tachytictic. The Chamberlainiini the only ectobranchous tribe within the Gonideinae (Table C1). 


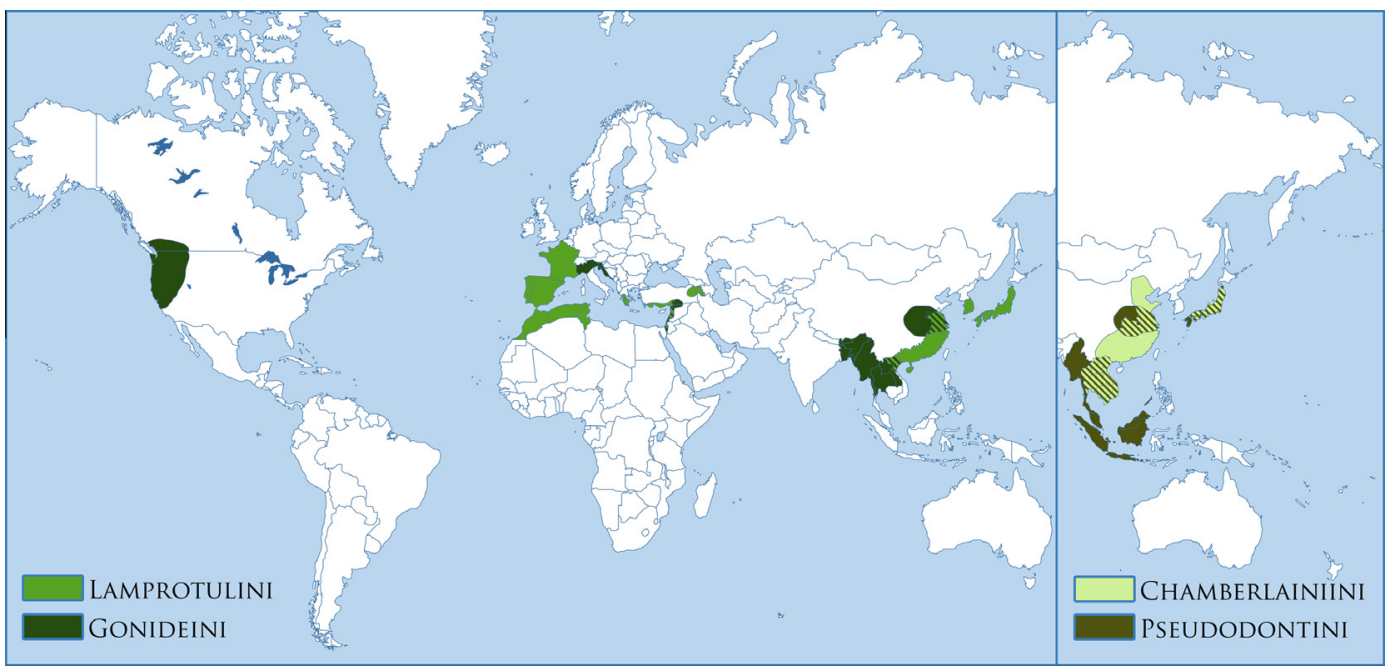

Fig. 6. Distribution map of the subfamily Gonideinae.

Distribution: Distribution of the Chamberlainiini is restricted to Indochina, the Huang He River basin in China, and Japan (Fig. 6).

\subsubsection{Tribe Lamprotulini Modell, 1942}

Type Genus: Lamprotula Simpson, 1900

Type Species: Chama plumbea Chemnitz, 1795

Comments: In addition to the type genus, the Lamprotulini include the western Palearctic Potomida and the Far East Asian Pronodularia. The Lamprotulini were first defined as a subfamily mainly based on characteristics of the umbo sculpture (Modell, 1942, 1964). It originally contained the genus Discomya, for which no genetic information is currently available, Lamprotula, Potomida and Pronodularia. Subsequently, all of these genera, with the exception of Pronodularia, were reassigned to Quadrulinae (Haas, 1969a, 1969b). However, Lamprotula, Pronodularia and Potomida were recently reassigned back to Gonideinae based on molecular, morphological and biogeographical studies (Pfeiffer and Graf, 2013, 2015; Whelan et al., 2011). The present study confirms the placement of these three genera within Lamprotulini.

Diagnosis: Shells are generally thick, and ovate to triangular in shape. Hinge with well-developed, strong teeth, generally three pseudocardinals and four laterals. Umbo sculpture consists of Wshaped to double-looped ridges, which sometimes become nodulous and/or wrinkled. Glochidia are semi-elliptical and unhooked, and of intermediate sizes (Table C1). Brooding type is tachytictic and tetragenous except for Pronodularia, which can be ectobranchous or tetragenous (Kondo, 1982) (Table C1). This tribe shares most of the traits with the other Gonideinae tribes, but all species present strong thick shells and well developed hinge teeth (Table C1).

Distribution: The Lamprotulini have a disjunct distribution, with Potomida presenting a patchy distribution in the Mediterranean region, Lamprotula being distributed from North Vietnam to North China and Korea, and Pronodularia restricted to Korea and Japan (Fig. 6).

\subsubsection{Tribe Gonideini Ortmann, 1916}

Type Genus: Gonidea Conrad, 1857

Type Species: Anodon randalli Trask, 1855 (Junior synonym of Anodonta angulata Lea, 1838)
Comments: The Gonideini are divided into two well supported clades, i.e., one encompassing the Western North American Gonidea, the Southern European Microcondylaea and the Middle Eastern Leguminaia, and the other with the Asian Solenaia. Solenaia is not monophyletic, as Solenaia triangularis was not recovered within the Gonideini (see Pfeiffer and Graf, 2015). The type genus Gonidea, as well as Leguminaia and Microcondylaea were originally placed within the Pseudodontinae with other Asian genera (Modell, 1942), but were all subsequently reassigned to the Unioninae (Haas, 1969a,b). Starobogatov (1970) placed these genera in the Pseudodontinae within the Margaritiferidae. Only recently, based on biogeographic and morphological information, Graf and Cummings (2016) suggested the placement of these genera within the Gonideinae. In the present study, molecular data confirms the placement of these three genera within the Gonideini together with some representatives of the genus Solenaia.

Diagnosis: Shell shape is trapezoidal but much more elongated in Solenaia. Hinge teeth are small, vestigial or absent in Solenaia. Umbo sculpture consists of pseudo-concentric, double-looped and/or W-shaped ridges, which are sometimes wrinkled. Glochidia are of intermediate sizes, semi elliptical and unhooked. Brooding type is tachytictic and tetragenous. Within the subfamily, the Gonideini are identified by a typical trapezoidal or rectangular shell shape, and a hinge without teeth or only vestigial teeth (Table C1).

Distribution: The tribe has a curious, disjunct distribution. While Gonidea is restricted to the west coast of North America, Microcondylaea only occurs from the Italian Peninsula to coastal Croatia in Europe, and Leguminaia is present in southeast Turkey and the Middle East. Solenaia occurs from eastern India to Myanmar, Thailand, North Vietnam and China (Fig. 6).

\subsubsection{Tribe Pseudodontini Frierson, 1927}

Type Genus: Pseudodon Gould, 1844

Type Species: Anodon inoscularis Gould, 1844

Comments: This group was first named as a subfamily, Pseudodontinae, by Frierson (1927) and included the species Pseudodon cambodjensis and Gonidea angulata. It was then redefined, mainly using morphological characters, with Pseudodon as the type genus together with other genera including the North American Gonidea (Modell, 1942, 1964). All of these genera were then subsequently reassigned to the Unioninae subfamily (Haas, 1969a,b; Subba 


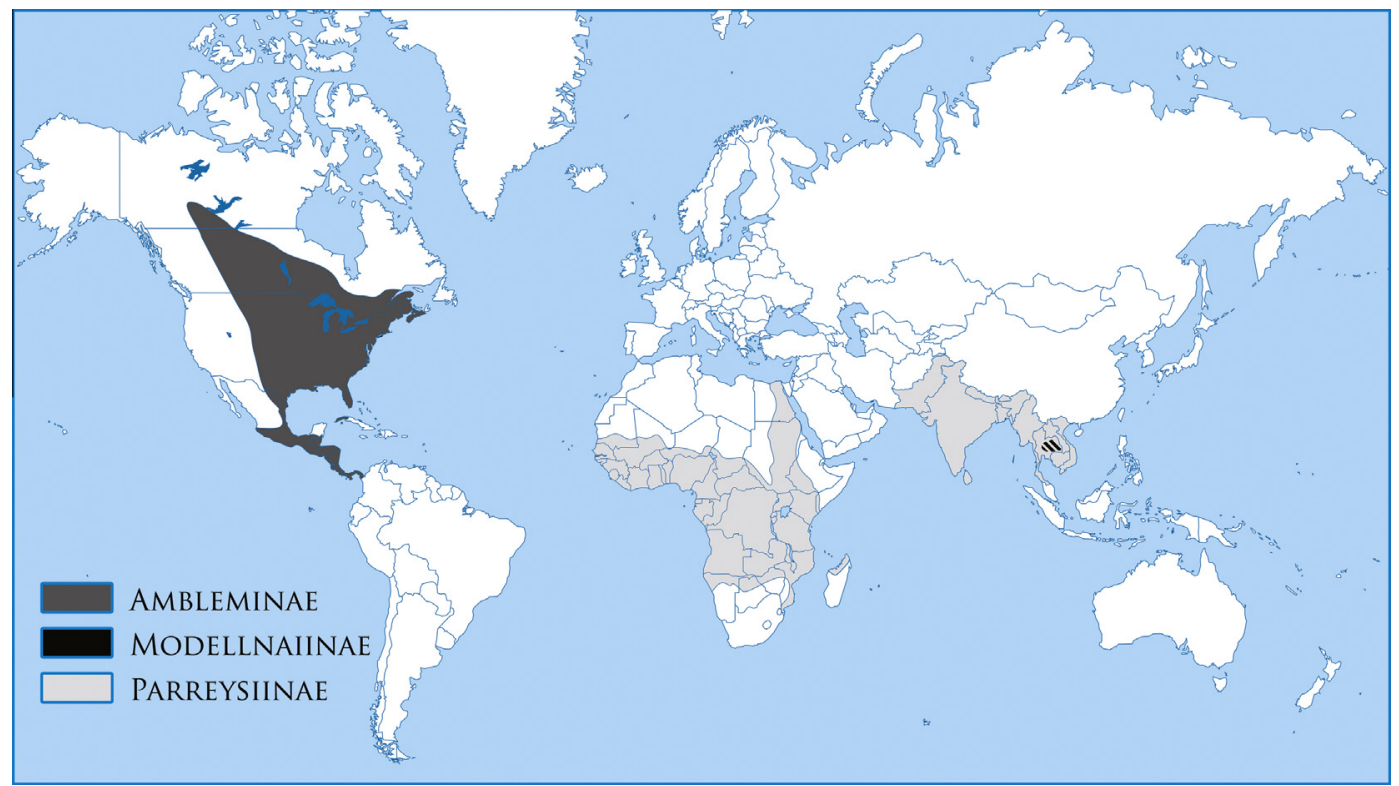

Fig. 7. Distribution map of the subfamilies Ambleminae + Modellnaiinae + Parreysiinae.

Rao, 1989), and only recently were their relationships with the Gonideinae discussed (Pfeiffer and Graf, 2015; Whelan et al., 2011). The Pseudodontinae is here demoted to a tribe, Pseudodontini, within Gonideinae, being composed of only two monophyletic genera, i.e., the type genus Pseudodon and Pilsbryoconcha (Fig. 2).

Diagnosis: Shell shape is generally ovate in Pseudodon and more elongated in Pilsbryoconcha. Umbo sculpture is basically doublelooped or W-shaped, with the anterior loops sometimes fading distally, so that only the posterior single-loop or a single row of nodes remains. Brooding type is tachytictic and tetragenous. Glochidia are unhooked and semi-elliptical. The representatives of this tribe present a characteristic " $v$ " shaped fossette present at the posterior end of the hinge structure with small vestigial teeth, which are completely absent in Pilsbryoconcha (Table C1).

Distribution: The Pseudodontini are present in Myanmar, Malaysia, Thailand, Cambodia, Laos, Vietnam, China and Indonesia including the Islands of Java, Sumatra and Borneo (Fig. 6).

3.6. Ambleminae Rafinesque, 1820, Parreysiinae Henderson, 1935 and Modellnaiinae Brandt, 1974

The Ambleminae and Parreysiinae were investigated in detail earlier (Campbell and Lydeard, 2012a,b; Campbell et al., 2005; Whelan et al., 2011) and thus not fully explored in the present study. The Modellnaiinae is a monotypic subfamily defined by Brandt (1974) with Modellnaia siamensis as the only species. Its status as a subfamily has been retained by posterior classification systems based on its quite distinct morphological characters (Bieler et al., 2010; Carter et al., 2011; Whelan et al., 2011; this study). Unfortunately, this species has never been included in a phylogenetic analysis and no sample was available for the present study.

Based on these earlier works and the present classification system, distribution maps are here presented for Ambleminae, Parreysiinae and Modellnaiinae (Table 3; Fig. 7). The Ambleminae are restricted to Canada and the United States east of the Rocky Mountains and extend south through Mexico to southern Panama. The Parreysiinae have a disjunct distribution in Africa and Southern Asia. In Africa, the Parreysiinae are found in the Nile River basin from the Nile delta south into East Africa and across sub-Saharan Africa south to Namibia and Mozambique. Germainaia Graf and Cummings, 2009 from northwest Madagascar is treated here as belonging to the Parreysiinae. In Asia, the Parreysiinae occur in Pakistan, India, Nepal, Myanmar, Thailand, Indonesia, Cambodia, Laos and Vietnam (Fig. 7). The Modellnaiinae (i.e., Modellnaia siamensis) is restricted to the middle section of Mun River in Thailand (Fig. 7).

\section{Conclusions}

Considering the high levels of decline of freshwater mussel species worldwide, an understanding of the phylogenetic diversity is crucial for determining conservation priorities, especially in poorly explored regions such as the Central American and the Indotropics. In fact, conservation strategies should strive not only to maximize the current levels of biological diversity, but also to include phylogenetic patterns to maximize future levels of biodiversity. Furthermore, due to the increasing development and biotic homogenization in tropical areas (e.g., Malaysia and Indonesia) with dramatic negative implications on freshwater habitats, conservation and management efforts targeting freshwater taxa are urgently needed.

The present study is an important contribution to the definition of freshwater mussel diversity patterns, especially in the Indotropical and East Asian countries. Here, a phylogeny of the Unionidae is presented with the greatest generic and geographic coverage to date, based on a dataset comprising 70 species in 46 genera, 7 of this genera being sequenced for the first time. Furthermore, it includes 57 species from 35 genera, thereby tripling the number of analyzed taxa from Anodontinae, Unioninae, Rectidentinae and Gonideinae. Molecular phylogenetic analyses revealed the presence of 6 subfamilies in the Unionidae, divided into 18 tribes, 3 of which are described here for the first time. Although we compiled seven characters traditionally used in Unionidae systematics, no single one was found to be diagnostic at the subfamily level and few were useful at the tribe level (e.g., larval morphology for Contradentini). However, within subfamilies, many tribes can be characterized based on a subset of these characters.

Representing a major international collaborative effort, this study provides important advances in the systematics of these extraordinary taxa with implications for ecological and conservation studies (e.g., assessment of conservation status and distribution). 


\section{Acknowledgments}

Financial support was provided by: the Portuguese Foundation for Science and Technology (FCT) Grant to EF (SFRH/ BPD/108445/2015); the Vietnam Academy of Science and Technology under grant number IEBR.CBT.TS07/2015 for the Vietnamese field research; the Central Michigan University Poyang Lake Research Investment Fund and the Key Laboratory of Poyang Lake Wetland and Watershed Research Director's Open Fund of Jiangxi Normal University for procurement of and analysis of some Chinese specimens. The authors wish to thank: Jamie Smith, Collection manager of Mollusks, North Carolina Museum of Natural Sciences, Raleigh, North Carolina, for all of her efforts to ship tissue samples to be used in this project; the Confederated Tribes of the Umatilla Indian Reservation for providing access to specimens of A. nuttalliana.

\section{Appendix A. Supplementary material}

Supplementary data associated with this article can be found, in the online version, at http://dx.doi.org/10.1016/j.ympev.2016.08. 021.

\section{References}

An, C., Ouyang, S., Zhou, C.-H., Wu, X.-P., 2016. The complete F-type mitochondrial genome of Chinese Anodonta arcaeformis (Bivalvia: Unionidae: Anodontinae). Mitochondrial DNA 27, 1552-1553. http://dx.doi.org/10.3109/ 19401736.2014.953133.

Araujo, R., Toledo, C., Machordom, A., 2009. Redescription of Unio gibbus Spengler, 1793, A West Palearctic freshwater mussel with hookless glochidia. Malacologia 51, 131-141. http://dx.doi.org/10.4002/040.051.0109.

Barnhart, M.C., Haag, W.R., Roston, W.N., 2008. Adaptations to host infection and larval parasitism in Unionoida. J. North Am. Benthol. Soc. 27, 370-394. http:// dx.doi.org/10.1899/07-093.1.

Bieler, R., Carter, J.G., Coan, E.V., 2010. Classification of bivalve families. In: Bouchet, P., Rocroi, J.-P. (Eds.), Nomenclator of Bivalve Families. Malacologia 52, pp. 113133.

Bogan, A.E., 2015. Determining the date of publication for Contradens Haas and Uniandra Haas (Bivalvia: Unionidae). Nautilus 129, 175-178.

Bogan, A.E., Hoeh, W.R., 2000. On becoming cemented: evolutionary relationships among the genera in the freshwater bivalve family Etheriidae (Bivalvia: Unionoida). Geol. Soc. London, Spec. Publ. 177, 159-168. http://dx.doi.org/ 10.1144/GSL.SP.2000.177.01.09.

Bogan, A.E., Roe, K.J., 2008. Freshwater bivalve (Unioniformes) diversity, systematics, and evolution: status and future directions. J. North Am. Benthol. Soc. 27, 349-369. http://dx.doi.org/10.1899/07-069.1.

Bogatov, V.V., 2012. Pearl mussels of the subfamily Nodulariinae (Bivalvia, Unionidae) in the Amur River Basin. Zool. Zh. 91, 393-403.

Bogatov, V.V., Starobogatov, Y.I., 1992. Pearl mussels from Southern Primorye. Zool. Zh. 71, 132-136.

Bolotov, I.N., Bespalaya, Y.V., Vikhrev, I.V., Aksenova, O.V., Aspholm, P.E., Gofarov, M. Y., Klishko, O.K., Kolosova, Y.S., Kondakov, A.V., Lyubas, A.A., Paltser, I.S., Konopleva, E.S., Tumpeesuwan, S., Bolotov, N.I., Voroshilova, I.S., 2015. Taxonomy and distribution of freshwater pearl mussels (Unionoida: Margaritiferidae) of the Russian Far East. PLoS ONE 10, e0122408. http://dx. doi.org/10.1371/journal.pone.0122408.

Brandt, R.A.M., 1974. The non-marine aquatic Mollusca of Thailand. Arch. für Molluskenkd. 105, 1-423.

Breton, S., Beaupré, H.D., Stewart, D.T., Hoeh, W.R., Blier, P.U., 2007. The unusual system of doubly uniparental inheritance of mtDNA: isn't one enough? Trends Genet. 23, 465-474. http://dx.doi.org/10.1016/j.tig.2007.05.011.

Breton, S., Stewart, D.T., Shepardson, S.P., Trdan, R.J., Bogan, A.E., Chapman, E.G., Ruminas, A.J., Piontkivska, H., Hoeh, W.R., 2011. Novel protein genes in animal mtDNA: a new sex determination system in freshwater mussels (Bivalvia: Unionoida)? Mol. Biol. Evol. 28, 1645-1659. http://dx.doi.org/10.1093/molbev/ msq345.

Campbell, D.C., Lydeard, C., 2012a. Molecular systematics of Fusconaia (Bivalvia: Unionidae: Ambleminae). Am. Malacol. Bull. 30, 1-17. http://dx.doi.org/ 10.4003/006.030.0101

Campbell, D.C., Lydeard, C., 2012b. The genera of Pleurobemini (Bivalvia: Unionidae: Ambleminae). Am. Malacol. Bull. 30, 19-38. http://dx.doi.org/ 10.4003/006.030.0102.

Campbell, D.C., Serb, J.M., Buhay, J.E., Roe, K.J., Minton, R.L., Lydeard, C., 2005. Phylogeny of North American amblemines (Bivalvia, Unionoida): prodigious polyphyly proves pervasive across genera. Invertebr. Biol. 124, 131-164. http:// dx.doi.org/10.1111/j.1744-7410.2005.00015.x.
Carter, J.G., Altaba, C.R., Anderson, L.C., Araujo, R., Biakov, A.S., Bogan, A.E., Campbell, D.C., Campbell, M., Jin-Hua, C., Cope, J.C.W., Delvene, G., Dijkstra, H.H., Zong-jie, F., Gardner, R.N., Gavrilova, V.A., Goncharova, I.A., Harries, P.J., Hartman, J.H., Hautmann, M., Hoeh, W.R., Hylleberg, J., Bao-Yu, J., Johnston, P., Kirkendale, L., Kleemann, K., Koppka, J., Kř́ǐž, J., Machado, D., Malchus, N., Márquez-Aliaga, A. Masse, J.-P., McRoberts, C.A., Middelfart, P.U., Mitchell, S., Nevesskaja, L.A., Ozer, S., Pojeta, J.J., Polubotko, I.V., Pons, J.M., Popov, S., Sánchez, T., Sartori, A.F., Scott, R.W., Sey, I.I., Signorelli, J.H., Silantiev, V.V., Skelton, P.W., Steuber, T. Waterhouse, J.B., Wingard, G.L., Yancey, T., 2011. A synoptical classification of the Bivalvia (Mollusca). Paleontol. Contrib. 4, 1-47.

Chong, J.P., Brim Box, J.C., Howard, J.K., Wolf, D., Myers, T.L., Mock, K.E., 2008. Three deeply divided lineages of the freshwater mussel genus Anodonta in western North America. Conserv. Genet. 9, 1303-1309. http://dx.doi.org/10.1007/ s10592-007-9485-X.

Clarke, A.H., 1981. The Freshwater Mollusks of Canada. National Museum of Natural Sciences, Ottawa, Ontario.

Cyr, F., Paquet, A., Martel, A.L., Angers, B., 2007. Cryptic lineages and hybridization in freshwater mussels of the genus Pyganodon (Unionidae) in northeastern North America. Can. J. Zool. 85, 1216-1227. http://dx.doi.org/10.1139/ Z07-104.

Đặng, N.T., Thái, T.B., Phạm, V.M., 1980. Định loại đ ng v t không Xương s ng nước ngot B c Vi t Nam. [The classification of freshwater invertebrates of North Vietnam]. Nhà Xu t bản Khoa học và Nhà Xu $t$ bảnKhoa học và Kỹ thu $t, H a n o i$, Vietnam (in Vietnamese).

Darriba, D., Taboada, G.L., Doallo, R., Posada, D., 2012. JModelTest 2: more models, new heuristics and parallel computing. Nat. Methods 9, 772. http://dx.doi.org/ 10.1038/nmeth.2109.

Davis, G.M., 1983. Relative roles of molecular genetics, anatomy, morphometrics and ecology in assessing relationships among North American Unionidae (Bivalvia). In: Oxford, G.S., Rollinson, D. (Eds.), Protein Polymorphism: Adaptive and Taxonomic Significance. Systematics Association, Special Volume. Academic Press, London, pp. 193-222.

Davis, G.M., 1984. Genetic relationships among some North American Unionidae (Bivalvia): sibling species, convergence, and cladistic relationships. Malacologia 25, 629-648.

Davis, G.M., Fuller, S.L.H., 1981. Genetic relationships among recent Unionacea (Bivalvia) of North America. Malacologia 20, 217-253.

Davis, G., Fuller, S., Hestermann, C., 1977. Toward a definitive higher classification of North American Unionacea. Bull. Am. Malacol. Union 85.

Davis, G.M., Heard, W.H., Fuller, S.L.H., Hesterman, C., 1981. Molecular genetics and speciation in Elliptio and its relationships to other taxa of North American Unionidae (Bivalvia). Biol. J. Linn. Soc. 15, 131-150. http://dx.doi.org/10.1111/ j.1095-8312.1981.tb00753.x.

Distel, D.L., Amin, M., Burgoyne, A., Linton, E., Mamangkey, G., Morrill, W., Nove, J., Wood, N., Yang, J., 2011. Molecular phylogeny of Pholadoidea Lamarck, 1809 supports a single origin for xylotrophy (wood feeding) and xylotrophic bacterial endosymbiosis in Bivalvia. Mol. Phylogenet. Evol. 61, 245-254. http://dx.doi. org/10.1016/j.ympev.2011.05.019.

Doucet-Beaupré, H., Blier, P.U., Chapman, E.G., Piontkivska, H., Dufresne, F., Sietman B.E., Mulcrone, R.S., Hoeh, W.R., 2012. Pyganodon (Bivalvia: Unionoida: Unionidae) phylogenetics: a male- and female-transmitted mitochondrial DNA perspective. Mol. Phylogenet. Evol. 63, 430-444. http://dx.doi.org/ 10.1016/j.ympev.2012.01.017.

Elderkin, C.L., Clewing, C., Wembo Ndeo, O., Albrecht, C., 2016. Molecular phylogeny and DNA barcoding confirm cryptic species in the African freshwater oyster Etheria elliptica Lamarck, 1807 (Bivalvia: Etheriidae). Biol. J. Linn. Soc. http://dx. doi.org/10.1111/bij.12734.

Farris, J.S., Kallersjo, M., Kluge, A.G., Bult, C., 1994. Testing significance of incongruence. Cladistics 10, 315-319. http://dx.doi.org/10.1111/j.10960031.1994.tb00181.x.

Folmer, O., Black, M., Hoeh, W., Lutz, R., Vrijenhoek, R., 1994. DNA primers for amplification of mitochondrial cytochrome c oxidase subunit I from diverse metazoan invertebrates. Mol. Mar. Biol. Biotechnol. 3, 294-299.

Frierson, L., 1927. A Classified and Annotated Check List of the North American Naiades. Baylor University Press, Waco, Texas.

Froufe, E., Sobral, C., Teixeira, A., Sousa, R., Varandas, S.C., Aldridge, D., Lopes-Lima, M., 2014. Genetic diversity of the pan-European freshwater mussel Anodonto anatina (Bivalvia: Unionoida) based on CO1: new phylogenetic insights and implications for conservation. Aquat. Conserv. Mar. Freshw. Ecosyst. 24, 561 574. http://dx.doi.org/10.1002/aqc.2456.

Froufe, E., Gonçalves, D.V., Teixeira, A., Sousa, R., Varandas, S., Ghamizi, M., Zieritz, A., Lopes-Lima, M., 2016a. Who lives where? Molecular and morphometric analyses clarify which Unio species (Unionida, Mollusca) inhabit the southwestern Palearctic region. Org. Divers. Evol. 16, 597-611. http://dx.doi. org/10.1007/s13127-016-0262-X.

Froufe, E., Gan, H.M., Lee, Y.P., Carneiro, J., Varandas, S., Teixeira, A., Zieritz, A., Sousa, R., Lopes-Lima, M., 2016b. The male and female complete mitochondrial genome sequences of the Endangered freshwater mussel Potomida littoralis (Cuvier, 1798) (Bivalvia: Unionidae). Mitochondrial DNA Part A 27, 3571-3572. http://dx.doi.org/10.3109/19401736.2015.1074223.

Giribet, G., Wheeler, W., 2002. On bivalve phylogeny: a high-level analysis of the Bivalvia (Mollusca) based on combined morphology and DNA sequence data. Invertebr. Biol. 121, 271-324. http://dx.doi.org/10.1111/j.1744-7410.2002. tb00132.x.

Graf, D.L., 2002. Molecular phylogenetic analysis of two problematic freshwater mussel genera (Unio and Gonidea) and a re-evaluation of the classification of 
Nearctic Unionidae (Bivalvia: Palaeoheterodonta: Unionoida). J. Molluscan Stud. 68, 65-71. http://dx.doi.org/10.1093/mollus/68.1.65.

Graf, D.L., 2007. Palearctic freshwater mussel (Mollusca: Bivalvia: Unionoida) diversity and the Comparatory Method as a species concept. Proc. Acad. Nat. Sci. Philadelphia 156, 71-88. http://dx.doi.org/10.1635/0097-3157(2007) 156[71: PFMMBU]2.0.CO;2.

Graf, D.L., 2013. Patterns of freshwater bivalve global diversity and the state of phylogenetic studies on the Unionoida, Sphaeriidae, and Cyrenidae. Am. Malacol. Bull. 31, 135-153. http://dx.doi.org/10.4003/006.031.0106.

Graf, D.L., Cummings, K.S., 2006. Palaeoheterodont diversity (Mollusca: Trigonioida + Unionoida): what we know and what we wish we knew about freshwater mussel evolution. Zool. J. Linn. Soc. 148, 343-394. http://dx.doi.org/10.1111/ j.1096-3642.2006.00259.x.

Graf, D.L., Cummings, K.S., 2007. Review of the systematics and global diversity of freshwater mussel species (Bivalvia: Unionoida). J. Molluscan Stud. 73, 291314. http://dx.doi.org/10.1093/mollus/eym029.

Graf, D.L., Cummings, K.S., 2016. The MUSSEL Project Database. <http://musselproject.uwsp.edu/db/> (accessed 15.01.16).

Graf, D.L., Foighil, D.Ó., 2000. The evolution of brooding characters among the freshwater pearly mussels (Bivalvia: Unionoidea) of North America. J. Molluscan Stud. 66, 157-170. http://dx.doi.org/10.1093/mollus/66.2.157.

Gustafson, R.G., Iwamoto, E.M., 2005. A DNA-based identification key to Pacific Northwest freshwater mussel glochidia: importance to salmonid and musse conservation. Northwest Sci. 79, 233-245.

Graf, D.L., Jones, H., Geneva, A.J., Pfeiffer, J.M., Klunzinger, M.W., 2015. Molecular phylogenetic analysis supports a Gondwanan origin of the Hyriidae (Mollusca: Bivalvia: Unionida) and the paraphyly of Australasian taxa. Mol. Phylogenet. Evol. 85, 1-9. http://dx.doi.org/10.1016/j.ympev.2015.01.012.

Haag, W.R., 2012. North American freshwater mussels. Natural History, Ecology, and Conservation. Cambridge University Press, Cambridge.

Haas, F., 1940. A tentative classification of the Palearctic unionids. Zool. Ser. Field Museum Nat. Hist. 24, 115-141.

Haas, F., 1969a. Superfamilia Unionacea. Das Tierrich, vol. 88. Walter de Gruyter, Berlin.

Haas, F., 1969b. Superfamily Unionacea. In: Moore, R.C. (Ed.), Treatise on Invertebrate Paleontology Part N, Volume 1, Mollusca 6. Geological Society of America. The University of Kansas, Bivalvia, pp. N411-N470.

He, J., Zhuang, Z., 2013. The Freshwater Bivalves of China. Conchbooks, Harxheim, Germany.

Heard, W., Guckert, R., 1970. A re-evaluation of the recent Unionacea (Pelecypoda) of North America. Malacologia 10, 333-355.

Hoeh, W.R., Black, M.B., Gustafson, R., Bogan, A.E., Lutz, R.A., Vrijenhoek, R.C., 1998 Testing alternative hypotheses of Neotrigonia (Bivalvia: Trigonioida) phylogenetic relationships using cytochrome C oxidase subunit I DNA sequences. Malacologia 40, 267-278.

Hoeh, W., Bogan, A., Cummings, K., Guttman, S., 2002b. Evolutionary relationships among the higher taxa of freshwater mussels (Bivalvia: Unionoida): inferences on phylogeny and character evolution from analyses of DNA sequence data. Malacol. Rev. 31-32, 123-141.

Hoeh, W.R., Bogan, A.E., Heard, W.H., 2001. A phylogenetic perspective on the evolution of morphological and reproductive characteristics in the Unionoida. In: Bauer, G., Wächtler, K. (Eds.), Ecology and Evolution of the Freshwater Mussels Unionoida. Springer-Verlag, Berlin, pp. 257-280.

Hoeh, W.R., Bogan, A.E., Heard, W.H., Chapman, E.G., 2009. Palaeoheterodont phylogeny, character evolution, diversity and phylogenetic classification: a reflection on methods of analysis. Malacologia 51, 307-317. http://dx.doi.org/ 10.4002/040.051.0206.

Hoeh, W.R., Stewart, D.T., Guttman, S.I., 2002a. High fidelity of mitochondrial genome transmission under the doubly uniparental mode of inheritance in freshwater mussels (Bivalvia: Unionoidea). Evolution 56, 2252-2261. http://dx. doi.org/10.1111/j.0014-3820.2002.tb00149.x.

Hoeh, W.R., Stewart, D.T., Sutherland, B.W., Zouros, E., 1996. Multiple origins of gender-associated mitochondrial DNA lineages in bivalves (Mollusca: Bivalvia). Evolution 50, 2276-2286. http://dx.doi.org/10.2307/2410697.

Hoggarth, M.A., 1999. Descriptions of some of the glochidia of the Unionidae (Mollusca: Bivalvia). Malacologia 41, 1-118.

Howells, R.G., Neck, R.W., Murray, H.D., 1996. Freshwater Mussels of Texas. Texas Parks and Wildlife Department, Inland Fisheries Division, Austin, Texas.

Huang, Y., Liu, H., Wu, X., Ouyang, S., 2002. Testing the relationships of Chinese freshwater Unionidae (Bivalvia) based on analysis of partial mitochondrial 16S rRNA sequences. J. Molluscan Stud. 68, 359-363. http://dx.doi.org 10.1093/mollus/68.4.359.

Huang, X.-C., Rong, J., Liu, Y., Zhang, M.-H., Wan, Y., Ouyang, S., Zhou, C.-H., Wu, X.P., 2013. The complete maternally and paternally inherited mitochondria genomes of the endangered freshwater mussel Solenaia carinatus (Bivalvia: Unionidae) and Implications for Unionidae taxonomy. PLoS ONE 8, e84352. http://dx.doi.org/10.1371/journal.pone.0084352.

Inoue, K., McQueen, A.L., Harris, J.L., Berg, D.J., 2014. Molecular phylogenetics and morphological variation reveal recent speciation in freshwater mussels of the genera Arcidens and Arkansia (Bivalvia: Unionidae). Biol. J. Linn. Soc. 112, 535545. http://dx.doi.org/10.1111/bij.12282.

Iredale, T., 1934. The freshwater mussels of Australia. Aust. Zool. 8, 57-78.

IUCN, 2015. The IUCN Red List of Threatened Species. Version 2015-4. <http://www. ucnredlist.org $>$.
Katoh, K., Standley, D.M., 2013. MAFFT multiple sequence alignment software version 7: improvements in performance and usability. Mol. Biol. Evol. 30, 772780. http://dx.doi.org/10.1093/molbev/mst010.

Klishko, O.K., 2001. Zoobeenthos of Transbaikal Lakes. Species Diversity, Distribution and Structural Organization. Siberian Branch Russian Academy of Sciences, BNC, Ulan-Ude.

Klishko, O.K., 2003. Atlas of Bottom Invertebrates of Transbaikal Lakes. ChSU, Chita, Russia.

Klishko, O.K., Lopes-Lima, M., Froufe, E., Bogan, A.E., 2014. Are Cristaria herculea (Middendorff, 1847) and Cristaria plicata (Leach, 1815) (Bivalvia, Unionidae) separate species? Zookeys 438, 1-15. http://dx.doi.org/ 10.3897 /zookeys.438.7493.

Kohler, F., Seddon, M., Bogan, A.E., Van Tu, D., Sri-Aroons, P., Aliens, D., 2012. The status and distribution of freshwater molluscs of the Indo-Burma region. In: Allen, D.J., Smith, K.G., Darwall, W.R.T. (Eds.), The Status and Distribution of Freshwater Biodiversity in Indo-Burma. IUCN, Cambridge, UK and Gland, Switzerland, pp. 66-85.

Kondo, T., 1982. Taxonomic revision of Inversidens (Bivalvia: Unionidae). Venus 41, 181-198.

Kondo, T., 2008. Monograph of Unionoida in Japan (Mollusca: Bivalvia). Special publication of the Malacological Society of Japan. No. 3.

Lea, I., 1836. A synopsis of the family of naïades. In: Cary, Lea and Blanchard. Philadelphia and John Miller, London.

Lea, I., 1838. A Synopsis of the Family of Naïades, second ed. Philadelphia.

Lea, I., 1852. A Synopsis of the Family of Naïades. Blanchard and Lea, Philadelphia. Lea, I., 1870. A Synopsis of the Family Unionidae. Henry C. Lea, Philadelphia.

Liu, Y., Zhang, W., Wang, Y., Wang, E., 1979. Freshwater Mollusk Economic Fauna of China. Science Press, Beijing (in Chinese).

Lopes-Lima, M., Teixeira, A., Froufe, E., Lopes, A., Varandas, S., Sousa, R., 2014. Biology and conservation of freshwater bivalves: past, present and future perspectives. Hydrobiologia 735, 1-13. http://dx.doi.org/10.1007/s10750-0141902-9.

Lopes-Lima, M., Hinzmann, M., Teixeira, A., Varandas, S., Machado, J., Sousa, R., Froufe, E., 2016a. The strange case of the tetragenous Anodonta anatina. J. Exp. Zool. A. Ecol. Genet. Physiol. 325, 52-56. http://dx.doi.org/10.1002/jez.1995.

Lopes-Lima, M., Sousa, R., Geist, J., Aldridge, D.C., Araujo, R., Bergengren, J., Bespalaya, Y., Bódis, E., Burlakova, L., Van Damme, D., Douda, K., Froufe, E. Georgiev, D., Gumpinger, C., Karatayev, A., Kebapçi, Ü., Killeen, I., Lajtner, J., Larsen, B.M., Lauceri, R., Legakis, A., Lois, S., Lundberg, S., Moorkens, E., Motte, G., Nagel, K.-O., Ondina, P., Outeiro, A., Paunovic, M., Prié, V., von Proschwitz, T., Riccardi, N., Rudzīte, M., Rudzītis, M., Scheder, C., Seddon, M., Şereflişan, H., Simić, V., Sokolova, S., Stoeckl, K., Taskinen, J., Teixeira, A., Thielen, F., Trichkova, T., Varandas, S., Vicentini, H., Zajac, K., Zajac, T., Zogaris, S., 2016b. Conservation status of freshwater mussels in Europe: state of the art and future challenges. Biol. Rev. published online 4 January 2016. doi: http://dx.doi.org/10.1111/brv. 12244.

Lydeard, C., Mulvey, M., Davis, G.M., 1996. Molecular systematics and evolution of reproductive traits of North American freshwater unionacean mussels (Mollusca: Bivalvia) as inferred from 16S rRNA gene sequences. Philos. Trans. R. Soc. Lond. B Biol. Sci. 351, 1593-1603. http://dx.doi.org/10.1098/ rstb.1996.0143.

Lydeard, C., Cowie, R.H., Ponder, W.F., Bogan, A.E., Bouchet, P., Clark, S.A., Cummings, K.S., Frest, T.J., Gargominy, O., Herbert, D.G., Hershler, R., Perez, K.E., Roth, B., Seddon, M., Strong, E.E., Thompson, F.G., 2004. The global decline of nonmarine mollusks. Bioscience 54, 321-330. http://dx.doi.org/10.1641/0006-3568(2004) 054[0321:TGDONM]2.0.CO;2.

Modell, H., 1942. Das natürliche system der najaden. Arch. für Molluskenkd. 74, $161-191$.

Modell, H., 1949. Das natürliche system der najaden 2. Arch. für Molluskenkd. 78, 29-46.

Modell, H., 1964. Das natürliche system der najaden 3. Arch. für Molluskenkd. 93. 71-126.

Moskvicheva, I.M., 1973a. Mussels of the subfamily Anodontinae (Bivalvia, Unionidae) in the Amur and Marine territory basin. Zool. Zh. 52, 822-834 (in Russian).

Moskvicheva, I.M., 1973b. Najades (Bivalvia, Unionoidea) of Amur River and Primorye territory. Zool. Zh. 52, 1458-1471.

Nagel, K., Badino, G., 2001. Population genetics and systematics of European Unionoidea. In: Bauer, G., Wächtler, K. (Eds.), Ecology and Evolution of the Freshwater Mussels Unionoida. Springer-Verlag, Berlin, Heidelberg, New York, pp. 51-80.

NCMNS, 2016. North Carolina Museum of Natural Sciences Online Collections: Invertebrates (accessed 15.01.16).

Nedeau, E.J., Smith, A.K., Stone, J., Jepsen, S., 2009. Freshwater Mussels of the Pacific Northwest. The Xerces Society, Portland, Oregon.

Ortmann, A.E., 1910. A new system of the Unionidae. Nautilus 23, 114-120.

Ortmann, A.E., 1911. A monograph of the najades of Pennsylvania. Parts I and II. Mem. Carnegie Museum 4, 279-347.

Ortmann, A.E., 1912. Notes upon the families and genera of the najades. Ann. Carnegie Museum 8, 222-365.

Ortmann, A.E., 1916. The anatomical structure of Gonidea angulata (Lea). Nautilus $30,50-53$.

Ortmann, A.E., 1919. A monograph of the najades of Pennsylvania. Part III. Mem. Carnegie Museum 8, 1-384. 
Ortmann, A.E., 1921. South American naiades: a contribution to the knowledge of the freshwater mussels of South America. Mem. Carnegie Museum 8, 451-670.

Ortmann, A.E., Walker, B., 1922. On the nomenclature of certain North American naiades. Occas. Pap. Museum Zool. Univ. Michigan 112, 1-75.

Ouyang, J., Wu, X., Ouyang, S., Li, S., Zhao, D., 2011. Phylogenetic analysis of some Chinese freshwater Unionidae based on mitochondrial COI sequences. J. Conchol. 40, 543-548.

Penn, O., Privman, E., Ashkenazy, H., Landan, G., Graur, D., Pupko, T., 2010. GUIDANCE: a web server for assessing alignment confidence scores. Nucleic Acids Res. 38, W23-W28. http://dx.doi.org/10.1093/nar/gkq443.

Pfeiffer, J.M., Graf, D.L., 2013. Re-analysis confirms the polyphyly of Lamprotula Simpson, 1900 (Bivalvia: Unionidae). J. Molluscan Stud. 79, 249-256. http://dx. doi.org/10.1093/mollus/eyt022.

Pfeiffer, J.M., Graf, D.L., 2015. Evolution of bilaterally asymmetrical larvae in freshwater mussels (Bivalvia: Unionoida: Unionidae). Zool. J. Linn. Soc. 175, 307-318. http://dx.doi.org/10.1111/zoj.12282.

Pfeiffer, J.M., Johnson, N.A., Randklev, C.R., Howells, R.G., Williams, J.D., 2015. Generic reclassification and species boundaries in the rediscovered freshwater mussel "Quadrula" mitchelli (Simpson in Dall, 1896). Conserv. Genet. published online 26 September 2015 doi: http://dx.doi.org/10.1007/s10592-015-0780-7.

Prashad, B., 1931. Some noteworthy examples of parallel evolution in the molluscan faunas of South-eastern Asia and South America. Proc. Roy. Soc. Edinburgh 51, 42-53.

Prié, V., Puillandre, N., 2014. Molecular phylogeny, taxonomy, and distribution of French Unio species (Bivalvia, Unionidae). Hydrobiologia 735, 95-110. http:// dx.doi.org/10.1007/s10750-013-1571-0.

Prozorova, L.A., Bogatov, V.V., 2006. Large bivalve molluscs (Bivalvia, Unioniformes) of Lake Baikal. Hydrobiologia 568, 201-205. http://dx.doi.org/10.1007/s10750006-0314-X.

Rambaut, A., Suchard, M.A., Xie, D., Drummond, A.J., 2014. Tracer v1.6. <http://beast. bio.ed.ac.uk/Tracer>.

Roe, K.J., Hoeh, W.R., 2003. Systematics of freshwater mussels (Bivalvia: Unionoida). In: Lydeard, C., Lindberg, D.R. (Eds.), Molecular Systematics and Phylogeography of Mollusks. Smithsonian Books, Washington, District of Columbia, pp. 91-122.

Ronquist, F., Teslenko, M., van der Mark, P., Ayres, D.L., Darling, A., Hohna, S., Larget, B., Liu, L., Suchard, M.A., Huelsenbeck, J.P., 2012. MrBayes 3.2: Effective Bayesian phylogenetic inference and model choice across a large model space. Syst. Biol. 61, 539-542.

Sambrook, J., Fritsch, E.F., Maniatis, T., 1989. Molecular Cloning: A Laboratory Manual. Cold Harbor Spring Press, New York.

Sharma, P.P., Zardus, J.D., Boyle, E.E., González, V.L., Jennings, R.M., McIntyre, E., Wheeler, W.C., Etter, R.J., Giribet, G., 2013. Into the deep: a phylogenetic approach to the bivalve subclass Protobranchia. Mol. Phylogenet. Evol. 69, 188204. http://dx.doi.org/10.1016/j.ympev.2013.05.018.

Simpson, C.T., 1900. Synopsis of the Naiades: or pearly fresh-water mussels. Proc. United States Natl. Museum 22, 501-1044.

Simpson, C.T., 1914. A Descriptive catalogue of the naiades, or pearly fresh-water mussels. Parts I-III. Bryant Walker, Detroit, Michigan.

Stamatakis, A., 2014. RAxML version 8: a tool for phylogenetic analysis and postanalysis of large phylogenies. Bioinformatics 30, 1312-1313. http://dx.doi.org/ 10.1093/bioinformatics/btu033.

Starobogatov, Y.I., 1970. Fauna Mollyuskov I Zoogeograficheskoe Raionirovanie Kontinental'nykh Vodoemov Zemnogo Shara [Mollusk Fauna and Zoogeographical Partitioning of Continental Water Reservoirs of the World]. Nauka, Leningrad (in Russian).

Subba Rao, N., 1989. Handbook Freshwater Molluscs of India. Zoological Survey of India, Calcutta, India.

Vinarski, M.V., Doroshenko, E.S., Karimov, A.V., 2007. New data on freshwater anodontine mussels (Bivalvia: Unionidae: Anodontinae) of the Western Siberian waterbodies. Bull. Russ. Far East Malacol. Soc. 11, 91-99.

Walker, J.M., Bogan, A.E., Bonfiglio, E.A., Campbell, D.C., Christian, A.D., Curole, J.P., Harris, J.L., Wojtecki, R.J., Hoeh, W.R., 2007. Primers for amplifying the hypervariable, male-transmitted COII-COI junction region in amblemine freshwater mussels (Bivalvia: Unionoidea: Ambleminae). Mol. Ecol. Notes 7, 489-491. http://dx.doi.org/10.1111/j.1471-8286.2006.01630.x.

Walker, J.M., Curole, J.P., Wade, D.E., Chapman, E.G., Bogan, A.E., Watters, G.T., Hoeh, W.R., 2006. Taxonomic distribution and phylogenetic utility of genderassociated mitochondrial genomes in the Unionoida (Bivalvia). Malacologia 48, 265-282.

Wang, G., Guo, L., Li, J., 2016. The F-type complete mitochondrial genome of Arconaia lanceolata. Mitochondrial DNA 27, 322-323. http://dx.doi.org/10.3109/ 19401736.2014 .892098$.

Whelan, N.V., Geneva, A.J., Graf, D.L., 2011. Molecular phylogenetic analysis of tropical freshwater mussels (Mollusca: Bivalvia: Unionoida) resolves the position of Coelatura and supports a monophyletic Unionidae. Mol. Phylogenet. Evol. 61, 504-514. http://dx.doi.org/10.1016/j.ympev.2011.07.016.

Whiting, M.F., 2002. Mecoptera is paraphyletic: multiple genes and phylogeny of Mecoptera and Siphonaptera. Zool. Scr. 31, 93-104. http://dx.doi.org/10.1046/ j.0300-3256.2001.00095.x.

Zanatta, D.T., Murphy, R.W., 2006. The evolution of active host-attraction strategies in the freshwater mussel tribe Lampsilini (Bivalvia: Unionidae). Mol. Phylogenet. Evol. 41, 195-208.

Zanatta, D.T., Ngo, A., Lindell, J., 2007. Reassessment of the phylogenetic relationships among Anodonta, Pyganodon, and Utterbackia (Bivalvia: Unionoida) using mutation coding of allozyme data. Proc. Acad. Nat. Sci. Philadelphia 156, 211-216.
Zatravkin, M.N., Bogatov, V.V., 1987. Large Bivalve Molluscs of Freshwater and Brackish Waters of the USSR Far East. DVO RAN USSR, Vladivostok.

Zhadin, V.I., 1938. Family Unionidae. Fauna of USSR. Mollusca, Vol. 4. AS USSR, Moscow and St.Petersburg, Russia.

Zhou, C.-H., Ouyang, S., Wu, X.-P., Li, M., 2007. Phylogeny of the genus Lamprotula Unionidae in China based on mitochondrial DNA sequences of 16S rRNA and ND1 genes. Acta Zool. Sin. 53, 1024-1030 (in Chinese).

Zieritz, A., Sartori, A.F., Bogan, A.E., Aldridge, D.C., 2015. Reconstructing the evolution of umbonal sculptures in the Unionida. J. Zool. Syst. Evol. Res. 53, 76-86. http://dx.doi.org/10.1111/jzs.12077.

Zieritz, A., Lopes-Lima, M., Bogan, A.E., Sousa, R., Walton, S., Rahim, K.A.A., Wilson, JJ., Ng, P.-Y., Froufe, E., McGowan, S., 2016. Factors driving changes in freshwater mussel (Bivalvia, Unionida) diversity and distribution in Peninsular Malaysia. Sci. Tot. Env. 2016. http://dx.doi.org/10.1016/j.scitotenv.2016.07.098.

\section{Further reading}

Bogan, A.E., 2008. Global diversity of freshwater mussels (Mollusca, Bivalvia) in freshwater. Hydrobiologia 595, 139-147. http://dx.doi.org/10.1007/s10750007-9011-7.

Bogatov, V.V., Sayenko, E.M., 2002. On the structure and systematic position of the genus Sinanodonta (Bivalvia, Unionidae). Bull. Russ. Far East Malacol. Soc. 7 85-93.

Bouchet, P., Rocroi, J., Bieler, R., Carter, J.G., Coan, E.V., 2010. Nomenclator of bivalve families. Malacologia 52, 1-184.

Cek, S., Sereflişan, H., 2011. The gametogenic cycle of Leguminaia whaetleyi (Lea, 1862) in lake Gölbaşı, Turkey (Bivalvia: Unionidae). J. Exp. Zool. Part A Ecol. Genet. Physiol. 315, 30-40. http://dx.doi.org/10.1002/jez.648.

Chatchavalvanich, K., Jindamongkon, P., Kovitvadhi, U., Thongpan, A., Kovitvadhi, S., 2010. Histological structure of gonads in the freshwater pearl mussel, Hyriopsis (Hyriopsis) bialatus Simpson, 1900. Invertebr. Reprod. Dev. 49, 245-253.

Chumnanpuen, P., Kovitvadhi, U., Chatchavalvanich, K., Thongpan, A., Kovitvadhi, S., 2011. Morphological development of glochidia in artificial media through early juvenile of freshwater pearl mussel, Hyriopsis (Hyriopsis) bialatus Simpson, 1900. Invertebr. Reprod. Dev. 55, 40-52. http://dx.doi.org/10.1080/ 07924259.2010 .548643 .

Clarke, A.H., 1985. The Tribe Alasmidontini (Unionidae: Anodontinae), Part II: Lasmigona and Simpsonaias. Smithsonian Institution Press, Washington, District of Columbia.

Duangsawang, L., Kovitvadhi, U., 2009. Reproductive cycle, glochidia development and culture of glochidia from the Freshwater Pearl Mussel Hyriopsis (Limnoscapha) desowitzi (Brandt, 1974) in artificial media. In: Proceedings of the 35th Congress on Science and Technology of Thailand (STT35) (Section G: Agricultural Science). Chonburi, Thailand.

Duangsawang, L., Kovitvadhi, U., Chatchavalvanich, K., 2008. Observation on the development of germ cells and marsupia in the freshwater pearl mussel hyriopsis (Limnoscapha) desowitzi. In: Proceedings of the 46th Kasetsart University Annual Conference (Subject: Science). Bangkok, Thailand, pp. 254260.

Heard, W., 1975. Sexuality and other aspects of reproduction in Anodonta (Pelecypoda: Unionidae). Malacologia 15, 80-103.

Hinzmann, M., Lopes-Lima, M., Teixeira, A., Varandas, S., Sousa, R., Lopes, A., Froufe, E., Machado, J., 2013. Reproductive Cycle and Strategy of Anodonta anatina (L., 1758): Notes on Hermaphroditism. J. Exp. Zool. Part A Ecol. Genet. Physiol. 319, 378-390. http://dx.doi.org/10.1002/jez.1801.

Inaba, S., 1941. A preliminary note on the glochidia of Japanese freshwater mussels. Annot. Zool. Jpn. 20, 14-23.

Jeong, K.H., Min, B.J., Chung, P.R., 1993. An anatomical and ultrastructural study of the glochidium of Anodonta arcaeformis. Malacol. Rev. 26, 71-79.

Kennedy, T.B., Haag, W.R., 2005. Using morphometrics to identify glochidia from a diverse freshwater mussel community. J. North Am. Benthol. Soc. 24, 880-889. http://dx.doi.org/10.1899/05-001.1.

Khalloufi, N., Boumaïza, M., 2009. First record and biology of Unio gibbus Spengler 1793 in Tunisia. Biologia 64, 1178-1183. http://dx.doi.org/10.2478/s11756009-0196-2.

King, T.L., Eackles, M.S., Gjetvaj, B., Hoeh, W.R., 1999. Intraspecific phylogeography of Lasmigona subviridis (Bivalvia: Unionidae): conservation implications of range discontinuity. Mol. Ecol. 8, S65-S78. http://dx.doi.org/10.1046/j.1365294X.1999.00784.x.

Kondo, T., 1987. Breeding seasons of seven species of unionid mussels (Bivalvia Unionidae) in a small creek. Venus 46, 227-236.

Kovitvadhi, S., Kovitvadhi, U., 2013. Effects of rearing density and sub-sand filters on growth performance of juvenile freshwater mussels (Chamberlainia hainesiana) reared under recirculating system conditions. ScienceAsia 39, 139-149. http:// dx.doi.org/10.2306/scienceasia1513-1874.2013.39.139.

Lima, P., Monteiro, S.M., Sousa, M., MacHado, J., 2012. A histological study of oogenesis in the freshwater mussel Anodonta cygnea (Linnaeus, 1758) in Mira Lagoon, Portugal. Malacologia 55, 251-261. http://dx.doi.org/10.4002/ 040.055 .0206$.

Liu, H.-P., Mitton, J.B., Wu, S.-K., 1996. Paternal mitochondrial DNA differentiation far exceeds maternal mitochondrial DNA and allozyme differentiation in the freshwater mussel, Anodonta grandis grandis. Evolution 50, 952-957. http://dx. doi.org/10.2307/2410870.

Mcivor, A.L., Aldridge, D.C., 2007. The reproductive biology of the depressed river mussel, Pseudanodonta complanata (Bivalvia: Unionidae), with implications for 
its conservation. J. Molluscan Stud. 73, 259-266. http://dx.doi.org/ 10.1093/mollus/eym023.

Nagel, K.-O., Castagnolo, L., Cencetti, E., Moro, G.A., 2007. Notes on reproduction, growth and habitat of Microcondylaea bonellii (Mollusca: Bivalvia: Unionidae) in the Torrente Versa (Italy). Mollusca 25, 41-49.

O’Brien, C., Nez, D., Wolf, D., Box, J.B., 2013. Reproductive Biology of Anodonta californiensis, Gonidea angulata, and Margaritifera falcata (Bivalvia: Unionoida) in the Middle Fork John Day River, Oregon. Northwest Sci. 87, 59-72. http://dx.doi. org/10.3955/046.087.0105.

Panha, S., 1990. The site survey and the study on reproductive cycles of freshwater pearl mussels in the central part of Thailand. Venus 49, 240-257.

Panha, S., 1993. Glochidiosis and juvenile production in a freshwater pearl mussel, Chamberlainia hainesiana. Invertebr. Reprod. Dev. 24, 157-160. http://dx.doi. org/10.1080/07924259.1993.9672347.

Panha, S., Eongprakornkeaw, A., 1995. Glochidium shell morphology of thai amblemid mussels. Venus 54, 225-236.

Pekkarinen, M., Englund, V.P.M., 1995. Sizes of intramarsupial unionacean glochidia in Finland. Arch. für Hydrobiol. 134, 379-391.

Sayenko, E.M., 2006. Morphology of Glochidia (Bivalvia: Unionidae: Anodontinae, Pseudoanodontinae). Dalnauka, Vladivostok, Russia.

Sayenko, E.M., 2012. New data on glochidia morphology of the freshwater mussel Pronodularia japanensis (Bivalvia: Unionidae) from Honshu Island, Japan. Bull. Russ. Far East Malacol. Soc. 15-16, 128-133.

Şereflişan, H., Menderes, Ş., Soylu, S., 2009. Description of Glochidia of Three Species of Freshwater Mussels (Unionidae) from Southeastern Turkey. Malacologia 51, 165-172. http://dx.doi.org/10.4002/040.051.0112.
Shu, F., Ouyang, S., Wu, X., 2012. Glochidial Morphology of Two Species of the Genus Schistodesmus (Bivalvia: Unionidae) from Lake Poyang, China. Am. Malacol. Bull. 30, 329-333. http://dx.doi.org/10.4003/006.030.0214.

Thiele, J., 1934. Handbuch Der Systematischen Weichtierkunde. Gustav Fischer, Jena, Germany.

Uthaiwan, K., Chatchavalvanich, K., Noparatnaraporn, N.V., Machado, J., 2001. Scanning electron microscopy of glochidia and juveniles of the freshwater mussel, Hyriopsis myersiana. Invertebr. Reprod. Dev. 40, 143-151. http://dx.doi. org/10.1080/07924259.2001.9652714.

Wächtler, K., Dreher-Mansur, M.C., Richter, T., 2001. Larval Types and Early Postlarval Biology in Naiads (Unionoida). In: Bauer, G., Wächtler, K. (Eds.), Ecology and Evolution of the Freshwater Mussels Unionoida. Springer-Verlag, Berlin Heidelberg, Germany, pp. 3-125. http://dx.doi.org/10.1007/978-3-64256869-5_6.

Wang, Y.-N., Zhang, G.-R., Wei, K.-J., Gardner, J.P.A., 2015. Reproductive traits of the threatened freshwater mussel Solenaia oleivora (Bivalvia: Unionidae) from the middle Yangtze River. J. Molluscan Stud. 81, 522-526. http://dx.doi.org/ 10.1093/mollus/eyv016.

Williams, J.D. Bogan, A.E. Garner, JT, 2008, Freshwater Mussels of Alabama and the Mobile Basin in Georgia, Mississippi, and Tennessee. University Alabama Press, Tuscaloosa.

Wu, X., Liang, Y., Wang, H., Ouyang, S., 1999. Morphological characters of glochidia of Unionidae and the taxonomic significance. Acta Hydrobiol. Sin. 23 (Supplem), 139-147. 